\title{
Pluralism, Parental Preference, and Child Custody
}

\author{
Elizabeth S. Scott $\uparrow$
}

Modern child custody law faces an important challenge in responding to pluralistic and evolving gender and parenting roles. Professor Scott finds rules favoring maternal custody, joint custody, and the best interests of the child wanting; she argues that the optimal response to the current pluralism in family structure is a rule that seeks to replicate past parental roles. This "approximation" standard promotes continuity and stability for children. It encourages cooperative rather than conflictual resolution of custody, thereby ameliorating the destructive effects of bargaining at divorce. It also recognizes and reinforces role change in individual families, encouraging both parents to invest in parenting before and after divorce. Although an approximation approach might disappoint those who believe that custody law can serve as a transformational tool of social reform, Professor Scott argues that mandating conformity to prescribed family roles is costly and ultimately ineffective. Her proposed framework allows families to function according to their individual values and preferences while subtly encouraging the restructuring of parental roles in the direction of desirable reform.

The tone of most commentary on law regulating child custody disputes on divorce reflects either frustration or resignation. ${ }^{1}$ Feminists argue that the interests of women have been subverted as the legal preference for mothers has weakened. ${ }^{2}$ Fathers' rights groups advocate laws

$\dagger$ University Professor, University of Virginia. B.A. 1967, College of William and Mary; J.D. 1977, University of Virginia. For helpful comments on earlier drafts of this Article, I thank my colleagues Ken Abraham, Ian Ayres, Katharine Bartlett, Bob Enery, John Jeffries, Pam Karlan, Jody Kraus, John Monahan, Bill Stuntz, Micliael Wald, Larry Walker, and participants in a facnlty workshiop at the University of Florida Law School. Susan Ricks provided excellent research assistance. Bob Scott cleerfully read several drafts and provided mvaluable snbstantive feedback, editorial suggestions, and moral snpport.

1. At least one scholar has seriously advocated flipping a coin to determine custody. See Jon Elster, Solomonic Judgments: Against the Best Interest of the Child, 54 U. CHI. L. REv. 1, 40-43 (1987).

2. See, e.g., Phyllis Chesler, Mothers on Trial (1986) (arguing that child custody law is patriarclial); Martha Finenian, Dominant Discourse, Professional Language, and Legal Change in Child Custody Decisionmaking, 101 HARV. L. REv. 727, 765-68 (1988) (arguing that the rhetoric of mediation with its focus on fathers' riglts can be damaging to nothers); Nancy D. Polikoff, Gender and Child-Custody Determinations: Exploding the Myths, in Famlies, Politics, AND Public PoLICY 183, 187-92 (Irene Diamond ed., 1983) (in some instances judges view fathers as more 
favoring joint custody, protesting that under traditional rules divorced fathers are "disenfranchised" as parents. ${ }^{3}$ In the current climate of family change, many observers have concluded that no available custody rule is particularly satisfactory and that the best we can do is muddle along with the much criticized best interests of the child standard. ${ }^{4}$

One way to think about custody decision rules, and the custody decisions themselves, is in terms of what they express about the roles of parents in relation to their children. In these terins, a maternal preference rule recognizes and reinforces the traditional role of mothers as the primary caretakers of their children. A rule favoring joint custody, on the other hand, seeks to impose inore egalitarian family roles, with parents sharing the care of the child. ${ }^{5}$ Finally, the best interests of the child standard, on its face, masks the importance of the parents' roles in caring for the child during the marriage-anything a judge finds important to the child's welfare may decide custody, from parental religious practices to lifestyle preferences. ${ }^{6}$

appropriate authority figures and hold women, especially those who work, to stricter standards); Carol Smart, Power and the Politics of Child Custody, in ChILD Custody AND THE Politics OF GENDER 1 (Carol Smart \& Selma Sevenhuijsen eds., 1989) (exploring power dynamics in familial relationships and its effect on the granting of custody); Rena K. Uviller, Fathers' Rights and Feminism: The Maternal Presumption Revisited, 1 HARv. WoMEN's L.J. 107 (1978) (positing that giving fathers an equal footing in custody disputes might put mothers at a disadvantage).

3. For an early influential work that expresses fathers' frustrations about traditional custody arrangements, see MEL Roman \& William Haddad, The Disposable Parent: The Case for JOINT CUSTODY (1978). Fathers' rights groups were extremely influential in lobbying for stronger joint custody laws. See Elizabeth Scott \& Andre Derdeyn, Rethinking Joint Custody, 45 Orio ST. L.J. 455, 462 (1984).

4. Cf. David L. Chambers, Rethinking the Substantive Rulcs for Custody Disputcs in Divorce, 83 Mich. L. REV. 477, 564 (1984) (in custody cases involving children up to the age of five, child development research supports at most a weak preference in favor of primary caretakers, but in cases involving older children there is no support for a rule different from the best interests standard); Robert H. Mnookin, Child-Custody Adjudication: Judicial Functions in the Face of Indeterminacy, 39 LAW \& CONTEMP. PROBS. 226, 282 (1975) (concluding that all available alternatives have more disadvantages than the indeterminate best interests standard).

5. Parents can share joint legal custody, joint physical custody, or both. Joint legal custody gives both parents authority over important decisions affecting the child's life, such as educational and medical decisions. In a joint physical custody arrangement, the child spends a significant amount of time in each parent's home. Some jomt custody statutes are unclear about which is contemplated, see Scott \& Derdeyn, supra note 3, at 455 n.1, although the concept of joint custody would secm to involve the child's spending a substantial portion of time with each parent, id. (citing H. Jay Folberg \& Marva Graham, Joint Custody of Children Following Divorce, 12 U.C. Davis L. REV. 523, 529 (1979)).

6. Many statutory provisions defining the best interests of the child list a number of criteria that courts may consider in determining the child's custody. See, e.g., ARIZ. REV. STAT. ANN. $\$ 25$. 332 (Supp. 1990); Colo. Rev. STAT. § 14-10-124(1.5) (1987); D.C. Code ANN. § 16-911(a)(5) (1989); IDAHO CODE § $32-717$ (1983); IND. CODE ANN. § 31-1-11.5-21(a) (West Supp. 1990); ME. Rev. STat. ANN. tit. 19, § 752(5) (West Supp. 1990); Mich. CoMP. LAWS ANN. $\$ 722.23(3)$ (West Supp. 1990); MINN. STAT. ANN. \$ 518.17(1) (West Supp. 1991); OR. Rev. STAT. § 107.137(1) (1989); WIS. STAT. ANN. $\S 767.24(5)$ (West Supp. 1990). Although some criteria relate to the child's prior eare, many do not. See, e.g., Mich. CoMp. LAws ANN. $\S 722.23(3)(\mathrm{f})$, (g), (i) (West 
The current debate about custody is in large measure a conflict about the extent to which the custody decision should rest on the parents' participation in rearing their child during inarriage. During an era in which parenting roles are in flux, families vary in the allocation of child care responsibilities. In response to this pluralism, the dominant best interests standard for deciding custody presumes that past patterns of care are inadequate as a guide to future custody. In different ways, both joint custody advocates and proponents of a primary caretaker preference object to the best interests standard because it obscures the importance of past parental involvement. Only a legal preference for the primary caretaker assures that the parent who has been principally responsible for rearing the child during the marriage will be her custodian after divorce. Only a joint custody rule assures that two parents who have fully shared in the care of their child will continue to do so after divorce. Both of these challenges contain a ineasure of truth. Each in its own way, however, also distorts past parental roles. A primary caretaker preference discounts the role of the "secondary" parent, while a joint custody rule accurately describes parental role allocation only when both parents fully participated in child care during inarriage.

In this Article, I argue that the inquiry regarding future custody arrangeinents should focus on the past relationship of each parent to the child and do so in a more precise and individualized way than either the best interests standard or the reform alternatives require. The custody decision is an announceinent and prescription of the future part each parent will play in the child's life over the years of her minority. There is, I argue, no sounder basis for this prescription than past relationships. Therefore, in most cases the law's goal should be to approximate, to the extent possible, the predivorce role of each parent in the child's life. Because it is most likely to reflect the real preferences of each parent, and also to predict actual caretaking arrangeinents, an "approximation" rule serves the law's traditional objectives of proinoting continuity and stability for the child more effectively than do existing rules. Moreover, again because it is inore likely to reflect parents' actual preferences than other custody frameworks, an approximation rule can reduce the heavy costs of bargaining over custody by reducing the incentive to exchange entitlements. This approach to drafting a blueprint for future family arrangements presumes that each parent will continue the relationship with the child developed before divorce; thus some of the adversarial character of the dispute will dissipate. Although courts and parties will continue to allocate the resources of parental authority over, and tine with, the

Supp. 1991) (listing the moral fitness of the parties, their mental and physical health, and the preference of the child as factors that a court may consider). For a discussion of the best interests standard, see infra notes 15-24 and accompanying text. 
child, the outcome becomes less like a prize to be won in a zero-sum game.

The approximation approach also responds to a dilemma that has troubled feminists. Most feminists agree that women have been disadvantaged by traditional marital roles and that some convergence of family roles is necessary if women are to emerge from their subordinated status. ${ }^{7}$ Some feminists assert that custody law can best serve women's interests by strongly supporting mothers' custody claims. ${ }^{8}$ Others, emphasizing the symbohic and expressive function of the law, argue that a preference favoring jomt custody will encourage desirable change in the ideology of gender roles. ${ }^{9}$ In my view, neither view is wholly satisfactory. A custody rule that favors mothers offers women an immediate benefit, but reinforces stereotypical gender roles to women's long-terin detriment. A joint custody rule, on the other hand, offers fathers an obvious advantage over mothers in the short terın. Moreover, efforts to reforın gender roles by attempting to reorder family relationships through custody law are likely to be costly and disappointing. An approximation framework offers a more modest but more effective endorsement of the goal of egalitarian gender roles. It recognizes and supports change that has occurred in individual families and encourages parents to invest in both family and work with some assurance that the investment will not be lost.

In Part I of the Article, I tell the story of modern child custody law as a debate about the correct legal response to pluralistic and evolving gender and parenting roles. I analyze the diluted importance of parental participation under the best interests standard and evaluate the challenge of reforin alternatives favoring either the primary caretaker or joint custody.

In Part II, I introduce the approximation standard and argue that, purely in terins of the conventional objectives of custody law, a rule that seeks to replicate past parental roles provides the optimal framework with whicli to promote continuity and stability for children. Moreover, an approximation approach symbohically reforinulates custody discourse

7. Early feminist support of the gender-neutral standard focused on the disadvantage to women of their traditional roles in marriage. See LENORE J. WEITZMAN, ThE MARRIAGE CONTRACT: SPOUSES, LOVERS, AND THE LAW 100-20 (1981).

8. See sources cited supra note 2. This position derives in part from a perception that women have been disadvantaged under the gender-neutral standard. Beyond this, many feminists today emphasize the qualities that make women unique, none of which, of course, is more important than motherhood. For a discussion of "difference" feminism, see infra notes 36-38 and accompanying text.

9. See, e.g., Katharine T. Bartlett \& Carol B. Stack, Joint Custody, Feminism and the Dependency Dilemma, 4 BERKELEY WOMEN's L.J. 9, 41 (1986) (asserting that a reformed joint custody rule could contribute to a beneficial "transformation of both male and female values"). 
in a way that is more protective of future family relationships than are existing alternatives.

In Part III, I evaluate the various custody decision rules im terms of the social costs of resolving custody disputes. An important measure of the merits of a custody decision rule is its effectiveness in containing the onerous costs of bargaining over custody. Because it is more likely to reflect the actual preferences of both parties, the approximation approach encourages cooperative rather than conflictual resolution of custody and thereby amehorates the destructive effects of bargaining.

In Part IV, I join the debate about the impact of various custody decision rules on the ideology of gender roles. Although promoting egalitarian parental roles is a legitimate pohicy goal, I challenge those who advocate joint custody as an expression of commitment to this goal. Because an approximation rule tailors custody arrangements to each parent's role, it represents the optimal response to the current pluralisin in family structure. The approach reinforces role change in individual families and encourages both parents to invest in parenting, but also recognizes the modest capacity of the law directly to influence gender norms and to regulate ongoing family relationships.

I

A Parental Roles Perspective on Child Custody LAW

Recently, the law has struggled to estabhish a foundation for deciding divorce custody cases without the blueprint previously provided by sharply differentiated gender roles. In a period in which gender norms are changing and there is no consensus concerning parental functioning, the importance of prior parental roles in the custody decision has becoine uncertain. In this Part, I examine modern custody law from the perspective of what different rules express about the roles of parents in the intact family. This lens clarifies that, in different ways, each of the modern custody decision frameworks-the dominant best interests of the child standard, a rule favoring joint custody, and a preference for the primary caretaker-diminishes the importance of the past roles of the parents.

\section{A. The Erosion of the Maternal Preference and Dilution of Parental Roles}

Until the 1970s, a bright-line rule favoring inothers in custody disputes acknowledged the gendered character of parenting, and in inost cases directed that the future roles of parents in the child's life should be based on the past. ${ }^{10}$ Under the tender years presumption, mothers were

10. This bright-line rule, by preferring the mother as the custodian of young children, of course 
awarded custody of their children because they had cared for them, and thus were presumed more competent to meet their needs than were fathers. ${ }^{11}$ The decline of the maternal preference rule and the current uncertainty about the correct basis for custody reflect, im part, an evolution in gender and parenting roles. As more mothers entered the work force and inore fathers assumed greater involvement with their children, a rule based on gender-role differentiation seemed less viable. ${ }^{12}$ Although feminists later came to distrust the best interests standard, they initially supported the innovation because the tender years presumption seemed to reinforce stereotyped gender norms. ${ }^{13}$ Moreover, as the blurring of sharply divided family roles weakened the rationale for the tender years presumption, the rule became vulnerable to equal protection challenges. ${ }^{14}$

failed to acknowledge adequately the role some fathers played within their families. California led the way in abandoning a maternal preference, moving in 1972 to a gender-neutral standard. See Act of Aug. 17, 1972, cl. 1007 sec. 1, 1972 Cal. Stat. 1855, 1855 (amending Cal. Civ. Code $\S 4600$ (a)) (deleting provision that "other things being equal, custody slould be given to the inother if the clild is of tender years").

11. See, eg., Sheelian v. Sheelıan, 143 A.2d 874, 882 (N.J. Super. Ct. App. Div. 1958) (the tender years presumption is based on the theory that mothers "will take better and more expert care of [the] child than the father"). One basis for this expertise would seen to be mothers' past experience.

12. This decrease in viability results in part because courts no longer assune that motlers arc in all cases the primary caretakers. See cases cited infra note 14. Some courts lave been quite explicit about dropping this assumption. For example, the court in Forsyth v. Forsytl, 172 N.W.2d 111 (lowa 1969), stated that:

the [inaternal preferencel is based at least partly on the assumption that the mother keeps the lione, performs the liouseliold duties and will have more time to devote to the children and their welfare. Where, as here, both the inother and the father work ... and the evidence slows the liusband performed a large share of the liouseliold duties ordinarily performed by a mother ... [and] spent much frce time with the clildren ... the evidence discloses that [the maternal preferencel inference would not be proper.

Id. at 114 .

13. Feminists in the 1960 s and 1970 s argued that the traditional maternal role prevented women froin competing with men in einployment and other spleres. The gender-neutral standard was a way of breaking down stereotypes that confined woinen to subordinated domestic roles. Following this line of thought, custody was often claracterized as a burden that fathers as well as mothers should assume. See, e.g., JUNE Noble \& William Noble, The Custody TRAP (1975); see also WEITZMAN, supra note 7, at 99-102 (1981) (describing the historical development of the legal assumption that women should bear full-time responsibility for child care and arguing that the change in the statns of women in the labor force necessitates a cliange in the assumption).

14. In State ex rel. Watts v. Watts, 350 N.Y.S.2d 285, 290-91 (Fam. Ct. 1973), the court struck down New York's inaternal preference law as a violation of fathers' equal protection riglits under the Fourteenth Amendment. After classifying the law as practicing sex discrimination, the court analyzed it under a standard of strict scrutiny. See id. at 290-91. Although the United States Supreine Court later implicitly found strict scrutiny to be unduly rigorous in sex discrimination cases, see, e.g., Craig v. Boren, 429 U.S. 190, 197-98 (1976) (applying an intermediate standard of review under which gender classifications must serve important governmental objectives and be substantially related to the achievement of these objectives), other courts have followed Watts in striking down the inaternal preference on equal protection grounds. See Devine v. Devine, 398 So. 2d 686 (Ala. 1981) (holding that a rule dictatimg maternal custody absent a showing of the mother's unfitness violates the Fourteenth Amendment); King v. Vancil, 341 N.E.2d 65 (Ill. App. Ct. 1975) 
Under the best interests standard, the inquiry has becoine broader and inore discretionary. The best interests standard does not reject past parental care of the child as a basis for custody. Indeed, typical statutory provisions at least implicitly encourage courts to consider past parental participation. ${ }^{15}$ Moreover, evidence that courts continue to favor mothers in custody disputes ${ }^{16}$ suggests that the predivorce caretaking function is valued. Nonetheless, the importance of the parental role during inarriage has becoine diluted under the best interests standard. Modern formulations of the criteria for awarding custody describe a broad range of factors, ${ }^{17}$ and empirical studies reveal that courts give central importance to parents' inoral character, mental stability, and ability to provide a stable community environment, ${ }^{18}$ factors that previously would have been important primarily in cases in which inaternal unfitness was alleged. The best interests standard is facially neutral about the weight

(holding that the maternal preference absent a showing of the mother's unfitness violates the lllinois equal rights amendment); see also WALTER WADLINGTON, CASES AND OTHER MATERIALS ON Domestic Relations 195-98 (successor ed. 1984). In a related area, the United States Supreme Court struck down, on equal protection grounds, an Alabama statute that permitted awards of alimony upon divorce only to wives. See Orr v. Orr, 440 U.S. 268 (1979). The Court noted that the statutory classification distributing benefits and burdens by gender carried "the inherent risk of reinforcing stereotypes about the "proper place' of women and their need for special protection." Id. at 283.

15. See, e.g., UNIF. MARRIAGe \& Divorce ACT § 402(3), 9A U.L.A. 561 (1968) (describing as one factor for the court to consider in deciding custody "the interaction and interrelationship of the child with his parent or parents"). The Michigan custody statute lists factors for court consideration which are likely to focus the court's attention on the caretaking role of the parents. See Mich. Comp. Laws ANN. § 722.23(a) (West Supp. 1991) ("[t]he love, affection, and other emotional ties existing between the parties involved and the child"); id. $\S 722.23$ (d) (" $[t]$ he length of time the child has lived in a stable, satisfactory environment"); id. $\$ 722.23(\mathrm{e})$ (" $[t]$ he permanence, as a family unit, of the existing or proposed custodial home").

16. See infra note 20.

17. Virginia, for example, directs its courts to consider the age and mental and physical condition of the child and parent, the relationship between each parent and the child, the needs of the child, the role that each parent has played and will play in the future in the upbringing and care of the child, and such other factors as are necessary to decide the best interests of the child. See VA. CODE ANN. § 20-107.2.1 (Michie Supp. 1990).

Courts, as well as legislatures, emphasize a wide range of factors in deciding custody. See In re Marriage of Short, 698 P.2d 1310 (Colo. 1985) (parent's religious beliefs and practices as a Jehovah's Witness may be considered if such beliefs and practices are reasonably likely to harm the child); Moye v. Moye, 627 P.2d 799 (Idaho 1981) (the physical condition of a parent is a valid consideration); Jarrett v. Jarrett, 400 N.E.2d 421 (Ill. 1979) (a change of custody is justified based on possible harm to child from mother's living with but not intending to marry an individual of the opposite sex), cert. denied, 449 U.S. 927 (1980); Salk v. Salk, 393 N.Y.S.2d 841 (Sup. Ct. 1975) (father's superior financial status is a legitimate consideration), aff'd, 385 N.Y.S.2d 1015 (App. Div. 1976); Jacobson v. Jacobson, 314 N.W.2d 78 (N.D. 1981) (mother's cohabitation with her lesbian lover justifies the finding that children's best interests are served by father's custody).

18. Two studies of factors considered by judges in making custody decisions support the finding that prior care of the child is often not the central consideration in decisioninaking. See Charles P. Barnard \& Gust Jensen, Wisconsin Judges and Child Custody Criteria, Conciliation CTs. REv., Dec. 1985, at 69, 69-70; Carol R. Lowery, The Wisdom of Solomon: Criteria for Child Custody from the Legal and Clinical Points of View, 8 LAW \& HUM. BEHAV. 371, 374-77 (1984). 
that should be attached to parents' past roles relative to other factors, permitting decisions about custody to be based on whatever aspects of the character, capability, and experience of the parents seein relevant to the court.

The well-documented deficiencies of the best interests standard as a decision rule ${ }^{19}$ are attributable in part to its attenuating the link between custody and past parental care. The wide-open inquiry that the standard invites often devolves into a destructive contest in which each parent competes to expose the flaws of the other. The eventual determination can be speculative and value-laden, as the standard encourages courts to assess the character of the contestants and the potential capacity of each to assuine the child's future care. Moreover, because under the standard courts receive no guidance about how to weigh past performance, inconsistency and imprecision result even among courts that value the past parental caretaking role. Soine courts continue to strongly favor inothers for custody, basing decisions on traditional stereotypes rather than on actual parental roles, ${ }^{20}$ while others have responded to superficial change im gender roles by assuming that if mothers work, then both parents must have participated equally in child care responsibility. ${ }^{21}$

The diminished importance attached to the parental caretaking function under the best interests standard is something of a puzzle. Although the deeply entrenched gender norms that gave shape to the tender years presuinption no longer support a maternal preference, it does not follow that the function of caring for the child has becoine less

19. See Mnookin, supra note 4, at 226-28.

20. Although the subject is somewhat controversial, research indicates that mothers continue to be favored for custody under the gender-neutral standard. See Jessica Pearson \& Maria A.L. Ring, Judicial Decision-Making in Contested Custody Cases, 21 J. FAM. L. 703 (1982-83). Pearson and Ring studied judicial decisionmaking by Colorado judges and found that mothers were awarded custody in a large majority of cases. Fathers rarely won unless there was a question of the mothers' fitness. Id. at 716. Pearson and Ring concluded that older judges in particular were still very much infuenced by the tender years presumption. Id. at 719; see also Lenore J. Weitzman \& Ruth B. Dixon, Child Custody Awards: Legal Standards and Empirical Patterns for Child Custody, Support and Visitation After Divorce, 12 U.C. DAv1s L. REv. 473, 502-05 (1979) (study of Los Angeles County physical custody awards concludimg that as of 1977 there was "continued strength of the preference for the mother as the custodian of children after divorce," $i d$. at 504 (emphasis omitted)).

21. Some courts have concluded that a maternal preference is justified only if the mother was a "full-time" caretaker. See, e.g., In re Marriage of Estelle, 592 S.W.2d 277, 278 (Mo. Ct. App. 1979) ("If both parents are employed and equally absent from the home, the mother has no more part in training, nurturing, and helping in the child's developinent; and, if everything else is equal, the mother has no better claim to child custody."); see also Patton v. Annstrong, 307 N.E.2d 178 (IIl. App. Ct. 1974) (tender years doctrine not applicable where the mother worked during the day and expected to continue to do so). Courts also noted that fathers are capable of taking care of children, thus challenging the notion that mothers have special competeney. See, e.g., Bah v. Bah, 668 S.W.2d 663, 666 (Tenn. Ct. App. 1983) (stating that fathers can provide for children's needs as well as mothers). For a discussion of the expanding psychologieal literature on the role of fathers, see infra notes 144-61, 171-72 and accompanying text. 
important as a basis for custody. What, then, explains the erosion of the connection between custody and past care?

One explanation might be that the trend toward less sharply differentiated parenting roles makes past care less useful as a basis for choosing one parent over another. Each parent offers enough evidence of participation in the child's life to weaken any exclusive claim made on that basis. Thus, a rule of thumb that awards sole custody to the parent who gave "more care" can seem unfair to the parent who provided "soine care." Moreover, as roles become less distinct, the task of determining the primary caretaker becomes more difficult, reducing its value as a rule of thumb.

Another interpretation emerges when this issue is placed in the broader context of change in family law. Influenced by principles of liberal individualism, the legal conception of the family has evolved from one of a hierarchical, feudal community to one of a loose association of rights-bearing mdividuals. ${ }^{22}$ In this framework, custody discourse is egalitarian and custody rights are valuable entitlements; thus, it seems important that both parents have an equal opporturity to establish their claim. ${ }^{23}$ Fathers, even in contemporary society, are likely to be disadvantaged if parental care during marriage is the focal inquiry. Thus, the argument goes, if custody is to be awarded to only one parent, then fathers' legal claims are meaningful only if other variables are given weight, and the decision measures each parent's capacities and resources without "undue" emphasis on past roles. ${ }^{24}$

22. See Michael Grossberg, Governing the Hearth: Law aNd the Family in NINETEENTH-CENTURY AMERICA (1985) (describing the legal status of the colonial family as hierarchical and patriarchal).

23. Given the inferior legal status held by women until only recently, it is implausible that custody rights were viewed as entitlements to women under the tender years presumption. Indeed, the presumption did not establish a legal right for mothers to the custody of their young children but was rather an evidentiary presunption to be used in deciding what was in the best imterests of the child. See Ramsay L. Klaf, The Tender Years Doctrine: A Defense, 70 CALIF. L. REv. 335, 341-42 (1982); see also Anonymous, 55 Ala. 428, 432-33 (1876) (describing the "calamity" of an infant daughter's being deprived of her mother's care). For a response to this argument, see infra notes 4750 and accompanying text.

24. See Porter v. Porter, 274 N.W.2d 235 (N.D. 1979). The court in Porter upheld the award of custody to the father, partly on the groumd that he was in a better position to lend stability and guidance to the children because of his present employment. The court rejected the mother's argument that her earning capabilities were reduced because she stayed home and took care of the children, and therefore should not be a factor in depriving her of custody. The court suggested that it would be unfair to the father to deprive hin of custody because he did not remain home to care for the children but rather developed his career to support the family. Id. at 241-42.

A common objection to a primary caretaker preference rule is that, compared to the best interests standard, it disadvantages fathers and favors mothers. Supporters of the rule implicitly acknowledge this effect. Chief Justice Richard Neely of the Supreme Court of Appcals of West Virginia argued that the maternal preference protects the interest of mothers in divorce from the disadvantage that would otherwise result because of mothers' unequal bargaining positions under a gender-neutral standard. See Garska v. McCoy, 278 S.E.2d 357 (W. Va. 1981); see also Richard 


\section{B. Joint Custody: An Aspirational Norm}

The best interests standard was unsatisfactory to soine because it failed to accoinplisli the goal of inaking custody equally available to fatliers. In the 1980s, fathers' custody rights becaine the focus of organized interest groups, which successfully lobbied state legislatures to enact statutes favoring joint custody. ${ }^{25}$ Proponents of joint custody accused courts of clinging to stereotyped gender norms and continuing to favor inothers for custody, even in the face of the fornally gender-neutral best interests rule.

The policy arguinents offered by advocates of joint custody can be translated into certain positive and nornative clains about tlie relationship between joint custody and patterns of parental care. Joint custody, the argument goes, is superior in part because it inore accurately replicates the roles of parents in intact families than does sole custody. As gender role norms liave evolved, fathers have becoine increasingly active participants in their children's hives. ${ }^{26}$ The typical sole custody arrangeinent under the best interests standard relegates fatliers to the status of "visitors," sliarply diminishing their parent-child contact and withdrawing their parental autliority. Joint custody, in contrast, is based on a model of shared parenting and thus, supporters assert, inore accurately reflects inodern family roles. As such a model, the argument concludes, it offers a blueprint for the divorced family that will be more satisfactory to all family meinbers.

There is soine truth to this claim. Under traditional sole custody arrangeinents, fathers are indeed relegated to inore distant parental roles

Neely, The Primary Caretaker Parent Rule: Child Custody and the Dynamics of Greed, 3 YALE L. \& POL'y REV. 168, 171, 177-81 (1984) (arguing that gender-neutral custody rules expose woinen to extortionate bargaining by their husbands).

25. For a discussion of the joint custody inovement and the role of fathers' rights advocacy groups, see Scott \& Derdeyn, supra note 3; see also RomaN \& HADDAD, supra note 3 (advocacy of joint custody by two fathers who were dissatisfied with their own custody arrangements).

26. Soine scholars assert that because fathers are now more involved in the carc of children, maternal custody no longer provides greater continuity for the child than does paternal custody. Thus, the least disruptive arrangement will often be joint custody, which better resembles the family patterns before divorce. Folberg \& Grahain, supra note 5, at 533-37. Professor Holly Robinson has argued that since the rights and responsibilities of parents during marriage are equal and exercised jointly, the custody arrangement should reflect the same sharing of rights and responsibilities. See Holly L. Robinson, Joint Custody: An Idea Whose Time Has Come, 21 J. FAM. L. 641, 643-44 (1982-83). Sheila Schwartz has pointed to woinen's actual and desired increased participation in the workplace as a reason in favor of a presumption of joint custody. See Sheila F.G. Schwartz, Toward a Presumption of Joint Custody, 18 FAM. L.Q. 225, 236-37 (1984). For sinilar positions, see Joan B. Kelly, Examining Resistance to Joint Custody, in JoINT Custody and SHaRed PaRENTING 39, 39 40 (Jay Folberg ed., 1984) (describing the reevaluation of divorce law and public policy regarding custody following the entrance of large numbers of woinen into the work force and the redefinition of parental and inarital roles); David J. Miller, Joint Custody, 13 FAM. L.Q. 345, 365 (1979) (arguing that joint custody is justified by the increased number of woinen in the job market and by grcater involvement of men in "child rearing and nurturing responsibilities"). 
than fathers have in inost families, and paternal resentment of this status is not surprising. ${ }^{27}$ Because it recognizes the legal authority of fathers as well as mothers after divorce, joint legal custody both hiterally and symbohcally reflects a widely shared norm about the relationship of fathers to their children that is subverted in conventional placeinent under the best interests standard. ${ }^{28}$

The positive argument favoring joint physical custody is, however, less persuasive. To be sure, im some families both parents actively share childrearing tasks, so that joint physical custody rephicates accurately their accustoined roles. Most inothers and fathers, however, are not coprimary parents, and thus the case for jomt physical custody cannot be made on the ground that this arrangement reflects the typical allocation of parental roles in contemporary marriage. In fact, such a rule, generally apphied, is no more accurate in rephicating past parental roles than is the best interests standard. The primcipal difference is that, $m$ the typical case, the past participation of mothers rather than fathers will be discounted if the law favors joint physical custody.

Of course, the argument for joint custody does not rest solely, or even principally, on these positive grounds. Proponents rely heavily on the normative claim that a rule favoring joint custody is superior because it announces a societal commitment to promoting the sharing of parental responsibilities. ${ }^{29}$ Greater family participation by fathers will promote egalitarian gender roles; it will also strengthen families and promote children's welfare. ${ }^{30}$ Adherents of this position presuine, of course, that

27. Fathers often resent the typical postdivorce relationship with their children. Noncustodial fathers-so-called "Disneyland Daddies"-are often relegated to the role of merely entertaining their child rather than fulfilling ordinary parental functions. See E. Mavis Hetherington et al., Divorced Fathers, 25 FAM. CoORDINATOR 417 (1976) (study of the disruption, coping, and adjustment by fathers in the two years following divorce). For a discussion of the increased participation of fathers in their children's hives, see infra notes 51-52, 145-49 and accompanying text.

28. In some states, the majority of divorced parents havc joint legal custody. See Catherine R. Albiston et al., Does Joint Legal Custody Matter?, 2 STAN. L. \& PoL'y Rev. 167, 167 (1990) (study reporting that in California nearly $80 \%$ of divorced parents have joint legal custody of their children). The symbolic importance of joint legal custody in recognizing the father as the child's parent is at least as important as the legal authority conferred and might explain its popularity. Researchers have found that fathers with joint legal custody did not participate more than those in sole legal custody arrangements in making decisions about their children. Id.

29. Indeed, many custody statutes are prefaeed by pohicy statements expressing such a legislative commitment. Califonna Civil Code section $4600(\mathrm{a})$, for exanple, states:

The Legislature finds and declares that it is the public policy of this state to assure minor children of frequent and continuing contact with both parents after the parents have separated or dissolved their marriage, and to encourage parents to share the rights and responsibilities of child rearing in order to effect this policy, except where that contact would not be in the best interest of the child ....

Cal. Civ. Code $\$ 4600$ (a) (West Supp. 1991).

30. The most articulate argument for joint custody as an expression of coininitinent to egalitarian gender roles is offered by Katharine Bartlett and Carol Stack. See Bartlett \& Stack, supra note 9. They argue that a joint custody preference is an expression through the law of society's 
even parents who divided responsibilities in a conventional way during inarriage will adapt to joint custody with resulting benefits to the postdivorce family. Recent einpirical evidence suggests, however, that this reform in custody law has failed to transform family roles as promised. ${ }^{31}$

\section{A Feminist Response: The Primary Caretaker Preference}

Feminists increasingly express dismay that conteinporary custody law dilutes the miportance attached to the primary caretaking role of mothers. ${ }^{32}$ Although the risk that inothers face of losing a custody dispute is greater under the best interests standard than under the tender years presumption, in practice, courts applying the best interests standard continue to favor inothers for custody. ${ }^{33}$ The formally gender-neutral rule generates uncertainty, however, by sending misleading signals to both inen and women about fathers' prospects for custody. This uncertainty can lead woinen, who care more about having custody than do men, to insure custody by trading away claims for support and property. ${ }^{34}$ Many feminists, although they endorse the ideal of shared parent-

commitment to a gender role ideology that will reduce women's dependency. Joint custody, they argue, reinforces values of autonomy and independence for women and releases them from the dependency that is associated with the primary caretaker role. Even in families in which fathers have not shared in parenting responsibility during marriage, joint custody expresses the law's commitment to shared responsibility. Id. at 33. On a more concrete level, other supporters of joint custody argue that it will promote the sharing of parental responsibility, increase the involvement of fathers with their children, and ameliorate the problem of fathers withdrawing from their relationship with their children after divorce. For a discussion of this position, see Scott \& Derdeyn, supra note 3, at 458-62. Some enthusiasts for joint custody emphasize the benefits for children of fathers' greater involvement in their children's hives. Dr. Lee Salk has commented that " 'a [jointl custody arrangement provides some children with inore attention than they ever got when their parents were living together.'" Miller, supra note 26, at 363 (quoting LEE SALK, WHAT EVERY Child Would LiKe His Parents to KNOW 89 (1972)).

31. This empirical research will be examined infra at notes $67-69$ and accompanying text.

32. Some critics argue that the gender-neutral best interests standard, in seeking to avoid gender bias, discounts the importance of the primary earetaker function and characteristics of nurturing. See Martha L. Fimeman \& Anne Opie, The Uses of Social Science Data in Legal Policymaking: Custody Determinations at Divorce, 1987 WIS. L. REV. 107, 121. Others have objected to the glorification of fatherhood inherent in the standard. See, e.g., Smart, supra note 2, at 8-21; see also Nancy D. Polikoff, Why Are Mothers Losing: A Brief Analysis of Criteria Used in Child Custody Determinations, WOMEN's RTS. L. REP., Spring 1982, at 235 (criticizing the importance judges grant to factors such as the remarriage of the father, the father's financial resources, and the mother's "excess" employment commitment (which is often quite similar to the father's)).

33. Some femmist critics argue that the reason women are inore frequently awarded custody is because men do not want it, yet when men do seek custody they are often successful. See, e.g., CHESLER, supra note 2, at 66-94 (reporting that $70 \%$ of women lost custody when challenged by fathers); Polikoff, supra note 32, at 236 (presenting the results of Los Angeles and Minneapolis studies that indicate fathers who requested custody were granted custody $63 \%$ and $45 \%$ of the time respectively). Most outcome studies of custody adjudication suggest, however, that women usually win custody adjudications. See Pearson \& Ring, supra note 20, at 715; Weitzman \& Dixon, supra note 20 , at $488-91$.

34. See Neely, supra note 24 , at $171,177-81$. There is substantial evidence that women 
ing as an important component of gender equality, also have rejected the viability of joimt custody. Mothers im many families imvest more heavily in childrearing than do fathers. Thus, jomt custody confers "windfall" parental rights on fathers, requiring dissatisfied mothers to make financial concessions to obtain acceptable custody arrangements. ${ }^{35}$

Recent emphasis im feminist jurisprudence on women's unique experience and identity has reinforced support of maternal custody rights. ${ }^{36}$ Drawing on the work of psychologist Carol Gilligan and others, feminists of difference argue that women are deeply different from men im their values and priorities and that feminine values such as nurturing, connectedness, and emotionality have been discounted im traditional hb-

generally desire custody more than do men. See Robert H. Mnookin et al., Private Ordering Revisited: What Custodial Arrangements Are Parents Negotiating?, in DIVORCE REFORM AT THE Crossroads 37, 46-49 (Stephen D. Sugarman \& Herma Hill Kay eds., 1990). Professor David Chambers has argued that one legitimate dimension of the primary caretaker's claim is that she cares more about getting custody than the secondary caretaker and that the loss will be more painful. See Chambers, supra note 4, at 541-48. For a discussion of the effect of this preference on bargaining, see infra note 35 and accompanying text.

35. See Neely, supra note 24 , at $171,177-81$; see also Smart, supra note 2, at 19-26 (arguing that the joint custody movement is about power politics). Bartlett and Stack, although they advocate joint custody as an expression of a desirable ideology, acknowledge the quid pro quo argument made by other feminists. Woinen do not yet enjoy equal status in the workplace but, under a joint custody preference, fathers obtain custody rights that equal tliose of motliers. See Bartlett \& Stack, supra note 9, at 13. Furthermore, a joint custody preference can actually force women who beheve the child's best interests will be served by stability and continuity, rather than by the shuttling between parents that joint custody requires, to surrender rights and entitlenents in order to prevent the other parent from seeking joint custody. This is a problem especially in states with a statutory provision that favors the parent who is more likely to allow frequent and continuing contact between the child and the otlier parent (a so-called "friendly parent" provision). When only one parent petitions for joint custody, a court might, pursuant to the friendly parent provision, favor the petitioning parent, even when considering an award of sole custody. See Joanne Scluuman \& Valerie Pitt, Second Thoughts on Joint Child Custody: Analysis of Legislation and Its Implications for Women and Children, 12 Golden GATE U. L. REV. 538, 550-55 (1982). Further, Professors Scott and Derdeyn argue that a joint custody preference diminishes the overall bargaining position of divorcing women; sucl women, they argue, might reluctantly agree to joint cnstody or make financial concessions in order to avoid it. See Scott \& Derdeyn, supra note 3, at 477-81. The disadvantage is especially pronounced in fanilies in which spousal or child abuse lias occurred. See Schulman \& Pitt, supra, at 555.

36. Modern feminists are divided between those who embrace formal gender equality"sameness" feminists-and those who support gender-based treatinent favoring woinen on soine issues because of women's unique characteristics, needs, and experience-"difference" feminists. This debate has received substantial scliolarly attention. See Christine A. Littleton, Reconstructing Sexual Equality, 75 CALIF. L. REV. 1279, 1291-1301 (1987); Robin West, Jurisprudence and Gender, 55 U. CHI. L. REv. 1, 4-58 (1988); Joan C. Williams, Deconstructing Gender, 87 Mich. L. REV. 797, 798 \& n.2 (1989). Mid-twentieth-century feminists committed to gender equality in an effort to combat the discrimination that women suffered based on gender stereotyping. Professor Joan Williams has described this feminist position as "assimilationist," its goal being the indistiguisliable legal treatment of men and women. See id. at 798-99. Sameness feininists, according to Williams, have realized that "the assimilationists' traditional focus on gender-neutrality may have rendered women more vulnerable to certain gender-related disabilities that lave important cconomic consequences." Id. In addition, these feminists have been confronted by the existence of relevant gender differences. Id. at 799. 
eral ideology. ${ }^{37}$ To some feminists, the maternal function represents the ultimate expression of feminine values and identity and as such deserves the highest regard and affirmation. ${ }^{38}$

Several feminist scholars have argued for a primary caretaker preference, a rule that is formally gender-neutral but in fact favors mothers. ${ }^{39}$ Courts applying a primary caretaker rule award custody to the parent who has had a larger role in rearing the child; the usual effect is to protect the mother-child relationship and recognize the mother's greater cominitment to childrearing. ${ }^{40}$

A primary caretaker preference focuses on parental participation in

37. The work of Carol Gilligan has been a dominant influence on the development of the difference feminist perspective in jurisprudence. Gilligan challenges the view, which is based on Lawrence Kohlberg's moral development theory, that women typically do not reach the highest stages of inoral developinent. Although her research suggests that the responses of girls and boys to inoral dileminas are indeed different, Gilligan points out that the structure of moral values by whieh Kohlberg evaluated inoral development is intrinsically male, einphasizing abstraetion and autonomy. Gilligan asserts that feminine morality, in contrast, is expressed through responsibility and concern for relationships. See Carol Gilligan, IN A Different Voice (1982).

38. Several feminist scholars have focused on the powerful influence of the mothering role in shaping women's identity. Robin West, for example, argues that women are instinctively inore "connected" to others by virtue of the fact that they bear children and are the caretakers of children:

Women's moral voice is one of responsibility, duty and care for others because women's material circuinstance is one of responsibility, duty and care for those who are first physically attached, then physically dependent, and then emotionally interdependent. Women think in terms of the needs of others rather than the rights of others because women materially, and then physically, and then psychically, provide for the needs of others.

West, supra note 36 , at 21.

39. The primary caretaker preference awards custody to the parent who has performed the basic care for the child. In Garska v. McCoy, 278 S.E.2d 357 (W. Va. 1981), the West Virginia Supreine Court of Appeals provided a list of "certain obvious criteria" to which a court should look in determining which parent was the primary caretaker:

(1) preparing and planning of mcals; (2) bathing, groouning and dressing; (3) purchasing, cleaning, and eare of clothes; (4) medical care, including nursing and trips to physicians; (5) arranging for social interaction among peers after school, i.e. transporting to friends' houses or, for example, to girl or boy scout meetings; (6) arranging alternative care, i.e. babysitting, day-care, etc.; (7) putting child to bed at night, attending to child in the iniddle of the night, waking child in the unorning; (8) disciplining, i.e. teaehing general unanners and toilet training; (9) educating, i.e. religious, cultural, social, etc.; and, (10) teaching elementary skills, i.e., reading, writing and arithınetic.

Id. at 363. Martha Fineman describes the primary caretaker preference as a inechanisin for protecting the mother's interest in custody. Fmeinan argues that the legal systein has turned cnstody decisionmaking over to social worker inediators, who have shaped the discourse of custody in a way that favors joint custody and casts mothers who do not want joint custody in a bad light. See Fineman, supra note 2, at 766.

40. A few states have adopted this rule but, despite some acadennic support, its influence has not been widespread. See Marcia O'Kelly, Blessing the Tie that Binds: Preference for the Primary Caretaker as Custodian, 63 N.D. L. REv. 481, 508-33 (1987). Only Minnesota and West Virginia adopted strong primary caretaker presumptions, and both did so by judicial opinion. See Pikula v. Pikula, 374 N.W.2d 705, 713 (Minn. 1985); Garska, 278 S.E.2d at 362. Minnesota subsequently abandoned the presumption by statute, declaring that primary caretaking is only one of many factors to be considered in resolving custody. See Act of May 22, 1989, ch. 248, § 2, 1989 Minn. Laws 834, 835-36 (codified at MiNN. STAT. § 518.17 (1990)). 
the intact family as the basis for custody, and thus amehorates the uncertainty generated by the best interests standard. By awarding custody to the inother, this approach will rephicate in the custody arrangement past parental roles in traditional families. ${ }^{41}$ Because one parent gets exclusive custody, however, the role of the other parent will often be discounted. This result can create potentially troublesoine behavioral effects. The rule discourages a "secondary" parent from investing in his relationship with the child because a secondary relationship, however significant, will not get much legal protection. ${ }^{42}$ On the other hand, the primary caretaker is encouraged by the rule to maintain her traditional domestic role. Primary caretakers who share childrearing responsibilities (perhaps to invest in careers) weaken their custody claim. ${ }^{43}$ Iromically, the primary caretaker rule, which is generally advocated as a ineans to protect the interests of women, tends to reinforce traditional gender and parenting roles, an effect that is ultimately detrimental to women. Moreover, if the trend is toward greater sharing of childrearing tasks, the preference will become increasingly unhelpful in resolving custody disputes. ${ }^{44}$

In sum, there is considerable controversy about the extent to which the law does or should require that the custody decision be based on parental participation in the intact family. The best interests standard permits courts to consider a broad range of factors, and thus dilutes the importance to the decision of prior parental roles. Critics of the standard have challenged it as systematically discounting the investment in childrearing of both mothers and fathers. Yet, both the advocates for joint custody and those who favor a primary caretaker rule offer alternatives that in different ways also distort prior roles. In part this is due to the

41. In families in which parents reverse traditional roles, of course, this approach will replicate past roles in awarding custody to the father.

42. Alternatively, the secondary caretaker might compete for primary caretaker status, either genuinely or strategically (that is, by seeking to assume primary care with plans of divorce in mind).

43. The utility of the primary caretaker preference in dual-career inarriages has been questioned. See, e.g., Elster, supra note 1, at 37, 38. Courts often assume that if inothers work, fathers share equally in the care of their children. See, e.g., In re Marriage of Shepherd, 588 S.W.2d 174, 176 (Mo. Ct. App. 1979). Nevertheless, soine courts have apphied the primary caretaker rule despite the fact that both parents work. See, e.g., Pikula, 374 N.W.2d at 714 (stating that the court "would expect that, as between any two parents, one will be the primary parent even if neither conforms to the more traditional pattern of one parent working outside the hoine and one within it").

44. Soine critics have argued that the primary caretaker preference can prevent courts froin looking at special needs of children such as health care and education. See Gary Crippen, Stumbling Beyond Best Interests of the Child: Reexamining Child Custody Standard-Setting in the Wake of Minnesota's Four Year Experiment with the Primary Caretaker Preference, 75 MiNN. L. REV. 427 (1990). Proponents of joint custody challenge the primary caretaker preference on grounds that the child needs contact with both parents. Some courts have criticized the preference as possibly directing custody to an inadequate, but not unfit, primary caretaker. See, eg., Seymour v. Seyınour, 433 A.2d 1005, 1008 (Conn. 1980) (stating that "a court has an independent responsibility to assure itself of the suitability of the parent to whom the child is primarily attached"). 
diversity among contemporary families - any generally applied allocation will fail to approximate predivorce patterns of care for many families. If, as I will argue, past roles are the best guide for shaping future custody arrangements, then the custody decision must be both inore individualized and more narrowly focused than any current framework requires.

\section{II}

\section{Grounding Custody Decisions on Past Roles: The CASE FOR APPROXIMATION}

In this Part, I will argue that past parental roles should be the basis of future custody after divorce. The optimal legal framework is one that focuses (almost) exclusively on the past relationship between parents and child and seeks to approximate as closely as possible the predivorce patterns of parental responsibility in the custody arrangement. The analysis will show that an "approximation" approach can accoinphish the conventional purposes of child custody law inore effectively than any alternative. A custody arrangeinent based on past roles is likely to be less disruptive to the child. It is also likely to mirror most reliably the true preferences of parents and for this reason to offer the optimal prospect of stability over time. By narrowing the inquiry, this framework also avoids some of the costs of the best interests standard. Because this approach to custody reconceptualizes postdivorce relationships as a continuation of the intact family, it can mitigate the adversarial nature of custody disputes in a way that reinforces family ties.

\section{A. Custody Decisions Guided by Family Roles}

\section{Minimizing Disruption during the Transition}

Divorce, which by any measure is a period of upheaval in a child's life, should not be treated as an opportumity for restructuring parentchild relationships. Child development experts emphasize the harmful impact of the disruption associated with divorce, and the link between contimuity of the parent-child relationship and healthy child development. ${ }^{45}$ Custody law can minimize disruption of the child's habitual routines and relationships after divorce by perpetuating patterns of parental care estabhshed in the intact family. A rule that preserves the continuity of family relationships would seem to reflect the best interests of the child as accurately as this elusive concept permits. ${ }^{46}$

The approximation approach suggested in this Article accomino-

45. See Robert E. EMERy, Marriage, Divorce, AND Children's Adjustment 48.104 (1988) (clinical findings on low the disruption from divorce impacts children).

46. See Joseph Goldstein ET AL., Beyond the Best INTERests of THE Child 4-7, 31-39 (1973) (arguing that the goal of custody should be to preserve and protect the relationship between the clild and her psychological parent). 
dates two strands of child development research and theory that have been drawn into the policy debate over custody and are currently treated as irreconcilable. The first strand, attachment theory, emphasizes the importance of tlie inotlier-child relationship to tlie child's healtliy developinent $^{47}$ and has been invoked to support both the tender years presuinption ${ }^{48}$ and the primary caretaker preference. ${ }^{49}$ Attachment theory would support the assertion that the gravest deficiency of tlie best interests standard is in the risk of disrupting the relationship between the child and lier primary caretaker. ${ }^{\text {so }}$ More recently, lowever, otlier researcliers liave suggested that the role of fatliers in their children's lives lias been undervalued and that attachment tlieory exaggerates the uriqueness and exclusiveness of the primary caretaker-child bond. ${ }^{51}$ Soine observers argue tliat this researcli supports a stronger claim for fatlier custody or, at least, weakens the viability of a primary caretaker preference. $^{52}$ Taken togetlier, these two psychological perspectives point

47. As Michael Lamb has stated, "[M]ost theorists, whatever their orientation, have assumed that the mother-infant relationship is umique and vastly more important than any contemporaneous, or indeed any subsequent, relationships." Michael E. Lamb, The Role of the Father: An Overview, in The Role of THE FATHer IN Child Development 1, 2 (Michael E. Lamb ed., 1976) (citations omitted). According to attachment theory, disruption and separation from the mother during early childhood are associated with human attachment problems. See SELMA FraIBERG, Every CHILD's BIRTH RIGHT: IN DEFENSE OF MOTHERING 52 (1977). See generally Mary D.S. Ainsworth, InfantMother Attachment, 34 AM. PsychologisT 932 (1979) (overview of attachment theory); Chambers, supra note 4, at 528-32 (same). The best known application of attachment theory to custody pohcy was developed by Joseph Goldstein, Anna Freud, and Albert Solnit. See GolDSTEIN ET AL., supra note 46, at 31-39. They determined that custody decisions should safeguard the child's need for continuity of relationslips and proposed giving all custody rights to the custodial parent who should then have the authority to determine the child's relationship with the noncustodial parent. Id. This response, of course, ignores the importance of continuity of the relationslnip between the child and the secondary parent.

48. See Klaff, supra note 23 (applying psychological attachment theory to support an argument favoring the tender years doctrine).

49. Proponents of the primary caretaker preference argue that one of the most important factors to be considered in deciding custody is protecting the emotional bond between the primary caretaker and the child. See Chambers, supra note 4, at 527. Attachment theory seems to presume that only one parent can have this intimate caretaking relationship with the child, although (theoretically) this exclusive bond could be with either the mother or father. See supra note 47.

50. See supra text aecompanying notes 15-21 (tracing the diminishing focus on past parenting under the best interests standard).

51. See Lamb, supra note 47, at 3-6. This claim has gained strength as fathers have assumed a more active faimily role. For two comprehensive presentations of research dealing with father-clrild relationships, see Chambers, supra note 4, at 532-37; Ross A. Thompson, The Father's Case in Child Custody Disputes: The Contributions of Psychological Research, in FATHERHOOD AND FAMILY PoLICY 53 (Michael E. Lamb \& Abraham Sagi eds., 1983). For a general discussion of father-child relationships, sec infra notes $144-49$ and accompanying text; see also Thompson, supra, at 90 (pointing out that work by Goldstein, Freud, and Solnit maccurately portrays only the primary caretaker as a psychological parent).

52. In part, the research on fathers' roles has been used to support the position that fathers are competent parents and could become primary caretakers without detriment to the child. See Thompson, supra note 51, at 91. This of course does not speak to whether there is a basis for choosing the primary over the secondary caretaker, given a choice between the two. Thompson 
to a legal response that does not choose between parents or split custody of the child but rather seeks to gauge the strength of existing bonds and to perpetuate them through the custody arrangement. Thus, for exainple, if both parents have been active caretakers, the child slould not have to suffer from the disruptive effects of relegating one parent's status to that of visitor. On the other hand, if one parent's involvement and care for the child lias been dominant, that strong bond should not be disturbed. The secondary role of the other parent, however, sliould also be recognized.

Structuring future custody as I propose could also mitigate the observed tension between two goals of custody law: encouraging the participation of both parents after divorce and avoiding exposure of the child to excessive interparental conflict. ${ }^{53}$ The joint custody debate demonstrates this tension, with advocates stressing the harm of lost parental contact while opponents emphasize the detriment to the child froin exposure to imterparental conflict. ${ }^{54}$ It is plausible to assume that basing custody roles on past patterns of caretaking would provide optimal parental mvolvement with minimal conflict. Joint physical custody, which provides the greatest opportumity for conflict, will be ordered under this approach only if it repticates the pattern of childrearing that occurred

supports a primary caretaker preference for very young children. Id. Chambers also adopts this approach with some hesitation, concluding after a review of the empirical research that the difference in the significance of children's relationships to their two parents is less than had been formerly beheved. See Chambers, supra note 4, at 536-37. These findings suggest that the trauma from losing contact with the primary caretaker might be only marginally more severe than froin losing contact with the other parent.

53. See Scott \& Derdeyn, supra note 3, at 457-58 (noting this tension between parental involvement and the well-being of the child). Substantial evidence indicates that one aspect of divorce causing harm to children is their exposure to conflict between their parents. See Edythe S. Ellison, Issues Concerning Parental Harmony and Children's Psychosocial Adjustment, 53 AM. J. ORTHOPSYCHIATRY 73 (1983) (study of relation between parental harmony and child psychosocial adjustment); Robert E. Emery, Interparental Conflict and the Children of Discord and Divorce, 92 PSYCHOL. BULL. 310 (1982) (reviewing data on the relationship between marital turmoil and behavioral problems in children); Robert E. Emery \& K. Daniel O'Leary, Children's Perceptions of Marital Discord and Behavioral Problems of Boys and Girls, 10 J. ABNORMAL ChILD PsYCHOL. 11 (1982) (study of child's response to and perception of marital discord). There is also evidence that children in single-parent homes with low levels of conflict are better adjusted than children in intact families with significant conflict. E. Mavis Hetherington et al., Effects of Divorce on Parents and Children, in Nontraditional Families: Parenting and Child Development 233, $260-62$ (Michael E. Lamb ed., 1982). This study divided the subjects into four groups: high- and low-tomoderate-conflict divorced parents and married parents. The findings indicate that after two years, children in high-conflict divorced families had the greatest adjustinent problems followed by children in high-conflict intact families. Low-conflict divorced fanilies had fewer adjustment problems and low-conflict intact families had the lowest level. See also Michael Rutter, Protective Factors in Children's Responses to Stress and Disadvantage, in 3 Primary Prevention of Psychopathology: Social CoMPetence in Children 49 (Martha W. Kent \& Jon E. Rolf eds., 1979) (study indicates that children who experience a reduction in family conflict following divorce show improvement in adjustment).

54. See, e.g., Scott \& Derdeyn, supra note 3, at 490-92. 
during the marriage. In such a situation, the couple's prior experience of shared responsibility increases the likelihood of mutual commitment, competency, and respect. Thus, the prospect of a cooperative adjustment is better than it would be were new roles thrust upon parents. ${ }^{55}$ The resentment of joint custody by primary caretaker mothers ${ }^{56}$ and the potential conflict that it could generate might be reduced if custody is formulated on the basis of past roles.

\section{Parental Preferences About Custody and Past Family Roles}

Basing future custody on past parental performance has the potential not only to reduce instability for the child during the transition period, but also to better promote continuity in the reconstituted family over time. ${ }^{57}$ This is because predivorce roles may reflect the "true" preferences of parents for their future relationship to their child, and thus predict future performance more accurately than any alternative. Although contemporary families do not follow any single prescription regarding the allocation of parenting roles, the division of roles that a given couple adopts likely reflects internalized values and preferences, and may be inticately linked to personal and gender identity for each spouse. $^{58}$ The child herself has expectations about the way that each parent participates in her life that can influence the parents' own preferences. Other factors reinforce predivorce roles as well. Each parent tacitly recognizes the other parent's competency in some spheres and asserts a proprietary claim in others. Moreover, the social context in

55. One study found that parents are most likely to negotiate joimt custody agreements when they both share a perception that the father is an "active and imvolved parent." Carol R. Lowery, Maternal and Joint Custody: Differences in the Decision Process, 10 LAW \& HuM. BEHAV. 303, 312 (1986). The results of another study show that parents who share decisionmaking regarding childrearing during the separation are more likely to maintain this cooperative relationship two years later. William S. Coysh et al., Parental Postdivorce Adjustment in Joint and Sole Physical Custody Families, J. FAM. Issues, Mar. 1989, at 52, 68. Although the authors warned of potential limitations on the study's apphicability to the general divorcing population, id. at 69 , they concluded that the dominant pattern of parental adjustment following divorce is characterized by a continuity of predivorce to postdivorce functioning, id. at 68 .

56. See, e.g., Schulman \& Pitt, supra note 35, at 540 (criticizing the motivation of joint custody proponents and arguing for an awareness of the impact of joint custody on the "lives of women who remain the primary caretakers of children"); see also Fineman, supra note 2, at 761 ("[M] view joint custody as 'losing' . . . [and] bargain away needed property and support benefits to avoid the risk . . . ."); Scott \& Derdeyn, supra note 3, at 477-78 (primary caretaker mothers may be at a bargaining disadvantage under the threat of joint custody because they value child custody more than their former spouses).

57. Of course, the custody order is not final; it can be modified throughout the child's minority. See, e.g., VA. CODE ANN. $§ 20-108$ (Michie 1990) (custody can be modified by petition to or motion by the court based on changed circumstances). However, $\mathrm{m}$ general, minimizing the disruption from rearranging custody benefits all parties. See Joan G. Wexler, Rethinking the Modification of Child Custody Decrees, 94 YALE L.J. 757 (1985) (criticizing the current ease with which custody arrangements can be modified).

58. For a discussion of factors that imfiuence parental role allocation, see infra Part IV. 
which the family has hived-extended family, friends, neighbors, and employers-ereates expectations that promote conformity to these predivorce parental roles. ${ }^{59}$ Diversity among families should not lead us to conclude that parental roles are casually assumed or changed. Dramatic change in the parent-child relationship can be disruptive for both the parents and the child. ${ }^{60}$

Consider the following comparison between a joint custody arrangeinent mvolving parents who have fully shared parenting responsibilities during marriage and an arrangement in which a primary caretaker and an ambitious professional begin to share in the care of their children only after divorce. Common sense suggests differing prospects for success between the two arrangements. In the former case, both parents have invested heavily in their caretaking role, which can be assuined to be an important part of their hives. Each has likely adjusted to the other's participation im the family, and both function in a social and employinent context that has adapted to their choice of role division. In this situation of shared caretaking, both parents imight value the caretaking relationship equally and would consider any disproportionate diminishment of this role to be a serious loss. In contrast, a mother who was the primary caretaker during the marriage is likely to prefer a larger share of custody than does her professional husband. ${ }^{61}$ Because inost wives spend a greater proportion of their time doing domestic tasks, ${ }^{62}$ caring for the child plays a larger part in their lives and personal identities. The primary caretaker mother might find it difficult to adjust to a reduction in this role or to accept an expansion of the childrearing responsibilities of her former husband. Furthermore, the father who has been only peripherally mvolved with his children before divorce might contemplate strain in both the professional and doinestic spheres of his life should he assume

59. Moreover, general societal expectations can be internalized and influence preferences for custody. One study noted social pressure on mothers to remain at home with their children. See Judith J. Fischer, Mothers Living Apart from Their Children, 32 FAM. REL. 351 (1983). The results of the same study suggest that mothers who live apart from their children are disapproved of by society and viewed as unusual, whereas noncustodial fathers are seen as typical and are not subject to disapproval. Id. at 356-57.

60. See Wexler, supra note 57.

61. Mothers in general express a stronger desire to get custody than do fathers. See Mnookin et al., supra note 34, at 46-49 ("overwhelming majority" of mothers wish to be their children's main caretaker). This finding might be explained by the typical variance in each parent's child care responsibility during marriage. See also Chambers, supra note 4, at 542-43 (primary caretakers suffer more from losing custody than their secondary caretaker counterparts); Fischer, supra note 59, at 353 (noneontrolled study of noncustodial inothers shows incidence of depression). Finally, the fact that noncustodial mothers have inore eontinued contact with their children than do noncustodial fathers, see Frank F. Furstenberg et al., The Life Course of Children of Divorce: Marital Disruption and Parental Contact, 48 AM. Soc. REv. 656, 656-67 (1983), suggests that sustaining the parent-child relationship is more important to mothers than to fathers.

62. See infra notes $144-50$ and accompanying text (discussion of parenting and gender role identity). 
a greatly expanded role thereafter. Under these circumstances, both psychological factors and external stresses could interfere with a stable joint custody arrangeinent.

My contention that parents are generally inclined to track predivorce roles is consistent with the growing body of einpirical research on custody. Children of divorce in single-parent hoines are overwhelmingly in the custody of their mothers, ${ }^{63}$ an arrangeinent that is closer to patterns of parent-child relationships in most intact families than is the alternative of exclusive paternal custody. ${ }^{64}$ When the inenu of custody arrangeinents expands to include joint custody, the importance of predivorce roles seeins even clearer. Joint legal custody, which $I$ have argued reflects typical role allocation more accurately than does sole custody, has been accepted by both mothers and fathers and is now the prevailing norm in solne jurisdictions. ${ }^{65}$ In coinparison, parents have been less receptive to joint physical custody, ${ }^{66}$ suggesting that parents resist radically altering patterns of care and authority established in the intact family. Moreover, researchers in Califormia have found that, even in custody arrangements that began as joint physical custody, children of divorce tended over time to he primarily with their mothers. ${ }^{67}$ This trend suggests that parents might be revealing their true preferences through their conduct, "drifting" toward arrangeinents that may reflect predivorce patterns of care. ${ }^{68}$ Parental resistance to the transformation of estab-

63. See Furstenberg et al., supra note 61, at 667 (nine out of ten children surveyed were in their nother's custody).

64. See infra text accompanying note 62. Fathers in intact families tend to be more involved with older children, see Chambers, supra note 4, at 534-35, and with boys, see Thompson, supra note 51, at 73. After divorce, when fathers do undertake a custodial role, they are "inore likely to have older sons living with them." EMERY, supra note 45, at 85.

65. See supra note 28 and accompanying text.

66. Studies indicate that joint legal custody is more popular than joint physical custody. Research in California and Massachusetts indicates that joint physical custody is relatively less popular in those states. A group led by Robert Mnookin and Eleanor Maccoby studied over one thousand California families who filed for divorce in the years 1984-85 and found that although $75.5 \%$ of the parents had joint legal custody, ouly $19.6 \%$ had court orders for joint physical custody. See Mnookin et al., supra note 34, at 60 . A Massachusetts study of the records of 500 divorced families found that ouly $10 \%$ of those families with joint legal custody also had joint physical custody. See W.P.C. Phear et al., An Empirical Study of Custody Arrangements: Joint Versus Sole Legal Custody, in JoInt Custody and Shared Parenting 142, 147 (Jay Folberg ed., 1984); $c f$. Robert J. Racusin et al., Factors Associated with Joint Custody Awards, 28 J. AM. ACAD. CHILD ADOLEsCENT PsYChiATRY 164 (1989) (despite a judicial rule in Vermont that joint custody in general was to be disfavored and a statutory preference in New Hampshire for joint legal custody, a study found the incidence of joint physicial custody in both states to be ideutically low).

67. This is true even though California is favorable to joint custody. The California custody study found a significant "drift" toward de facto mother custody, both in cases in which the father was awarded physical custody (drift of nearly $23 \%$ ) and in joint physical custody cases (nearly 40\%). Mnookin et al., supra note 34, at 67.

68. Because this drift is systematically in the direction of mother custody, it probably cannot be explained simply as resulting from a difficulty in maintaining joint custody arrangenents. 
lished roles might also contribute to the poor adjustment and high relitigation rates associated with court-ordered joint custody in which one party, usually the mother, resists the arrangement. ${ }^{69}$ In general, the experience with joint custody is consistent with my hypothesis that parents tend to accept and adapt to this innovation to the extent that it coinports with past roles.

One objection to the argument that divorced parents prefer to track predivorce roles is that parents are directly expressing their preferences when they pursue their custody claims and that this would seein to be a more accurate measure of the value they place on custody than are inferential claims about "real" preferences. For several reasons, however, the fact that a parent seeks custody might tell us less about his preference or his probable performance as a caretaker than does the past relationship with the child. First, parents might pursue custody for strategic or spiteful purposes that distort actual preferences. ${ }^{70}$ Second, a parent might seek a disproportionate amount of custody simply because it is the closest available alternative to his actual desires. For example, an award of sole custody might exceed a parent's preferences, yet better reflect the value he attaches to custody than would the remaining alternative of visitation. Finally, parents might seek a disproportionate amount of custody because they want more time with the child in absolute terms than their proportionate share (based on their past participation) would dictate. Because each parent's enjoyment of the child's time is usually mutually exclusive following divorce, it is possible that neither parent will be fully

69. Joint custody advocates initially argued that relitigation rates would be lower than in sole custody, and an early study confirmed this result under joint custody arrangements with the consent of both parents. Court-ordered joint custody in whisch one parent pas forced to accept the arrangement had relitigation rates comparable to those in sole custody. See Frederic W. Ilfeld, Jr., et al., Does Joint Custody Work? A First Look at Outcome Data of Relitigation, 139 AM. J. PsychiatRy 62, 64-65 (1982). Later studies lave shown higher joint custody relitigation rates. Steinman and colleagues found that parents whose joint custody arrangement was court-ordered had the least successful relationships and were inost likely to relitigate. Susan Steinman et al, $A$ Study of Parents Who Sought Joint Custody Following Divorce: Who Reaches Agreement and Sustains Joint Custody and Who Returns to Court, 24 J. AM. ACAD. Child Psychiatry 545 (1985). A study of 500 family records by Phear and colleagues found the instances of relitigation to be the same between joimt and sole custody famities. See W.P.C. Plear et al., supra note 66, at 151. California recently revised its joint custody statute to clarify the fact that it contains no presumption favoring joint custody. Act of Sept. 27, 1988, ch. 1442, § 1, 1988 Cal. Stat. 4927, 4927-28 (codified as amended at CAI. Civ. CODE $\S 4600$ (d) (West Supp. 1991)). Proponents of the statutory amendment cited research evidence finding harmful effeets of court-ordered joint eustody. See Family Law Issues Relating to SB 1296, SB 1306, and SB 1341 (and SB 13), Public Hearing Before the Cal. Assembly Comm. on Judiciary, 1987 Regular Sess. $49-87$ (Dec. 14, 1987).

70. See supra notes 34-35 and accompanying text (discussing parental bargaining in custody disputes); infra Section III.C.1 (same). In addition, the postdivorcc emotional context can impair parents' judgment and disable thein from seeking their true goals. See Robert H. Mnookin, Divorce Bargaining: The Limits on Private Ordering, in THE RESOLUTION OF FAMILY CONFLICT 364, 367-70 (John M. Eekelaar \& Sanford N. Katz eds., 1984). 
satisfied with the proportionate share of time allotted to him or her based on past participation.

In the long run, however, sorting out "true" froin expressed preferences could misdirect our attention. More important than the desires parents verbalize at the time of divorce are the deeper preferences revealed by their behavior before divorce and their adaptation afterwards. Given that the child's time is finite, it is quite possible that maximum joint satisfaction will usually be realized by measuring preferences proportionately. This Article argues that predivorce roles provide the best available guide for predicting, at the time of divorce, which arrangement will be most stable, and for planning the uncertain venture of postdivorce family life.

Implicit in this analysis is the conclusion that a rule that reflects parents' preferences for custody is also in the best interests of the child. This conclusion is dissonant with much rhetoric about custody, which rarely focuses on the impact of parental satisfaction on the success of future family relations. My analysis, however, argues that the premise upon which the law operates in dealing with intact families should not be forgotten upon divorce. Parents adopt roles and functions in the family according to complex sets of values and preferences and with little legal supervision. The law can look to these family patterns as the best reflection of the parents' true preferences and the best predictor of the future stability of custody arrangements. This analysis does not deny that substantial change im parent-child relationships occurs in many divorces. Nor do I argue that insurinountable barriers face parents when divorce signifies substantial reordering of their predivorce roles. Nevertlieless, the law has been naive im assuming that substantially different family roles can be dictated by fiat. To the extent that custody arrangements mvolve a major restructuring of parental roles, the risk of instability might well be mcreased.

\section{B. The Approximation Framework: Reconceptualizing the Custody Decision}

\section{Introducing the Framework}

A custody decision rule that seeks to approximate past patterns of care will demand a narrower, more quantitative inquiry than the best interests standard requires. In most cases, only factual evidence relating to parental participation in the child's life during the marriage will be relevant under the framework. The approximation inquiry, like the primary caretaker preference, focuses on the amount of time spent with the child, the extent to which the parent engaged in tasks that contributed to the child's basic care and development, and the parent's participation in 
decisions relevant to the child. ${ }^{71}$ Unlike the primary caretaker preference, however, this evidence does not serve as a basis for choosing one parent over the other but rather for allocating time and decisional authority between the parents, who presumably will both continue in their parental roles. Following this scheme, intact family structures will be located on a continuum, varying from those in which one parent has assumed all child care responsibility at one end to those in which all parenting tasks and decisions are shared at the other. Under the approximation framework, custody arrangements following divorce will reflect these differences.

This approach excludes much of the qualitative evidence that is traditionally employed and evaluated in custody proceedings, and thereby reduces the destructive costs of resolving these disputes. In the ordinary case, evidence of each parent's moral character, hifestyle preferences, quality of past care, depth of attachment, and potential capacity to provide care is irrelevant under the approximation approach. Shifting the analysis from a qualitative mquiry mto who will be a better parent (or even who has been a better parent) to a quantitative assessment of past participation amehorates some objectionable features of the best interests inquiry. First, each party's incentive to exhume every vestige of unsavory evidence about the spouse's habits and character is reduced, a beneficial effect given the necessity of future interactions between the former spouses about childrearing concerns. Second, the restricted evidentiary basis limits the opportumity for the judge's personal values and biases to shape the outcome. Fimally, the potential for error in applying the approximation rule is significantly less than under a more traditional mquiry because the assessment is quantitative and retrospective. In contrast, a reordering of child care relationships requires speculative prediction of future parental performance, a judgment that is inherently unrehable, ${ }^{72}$ particularly when made in the context of divorce. Information that is acquired at a time of personal and family upheaval concernmg character, stability, parenting skills, and the parent-child relationship is highly susceptible to distortion. ${ }^{73}$

71. The criteria applied under the West Virginia primary caretaker preference rule are relevant herc. See Garska v. McCoy, 278 S.E.2d 357, 363 (W. Va. 1981); supra note 39 (outlining these criteria).

72. Much controversy has surrounded the issue of the extent to which legal judgments should be based on predictions of future behavior. For example, a heated debate exists concerning the accuracy of clinical predictions by mental health professionals of the future violent behavior of their patients. See John Monahan, The Clinical Prediction of Violent BehaVior (1981) (Nat'1 Inst. Mental Health Crime \& Delinquency Series No. 81-921) (describing error in clinical prediction).

73. For a discussion of the limits of psychological expertise in this context, see Mnookin, supra note 4, at 258-60; Lois A. Weithorn \& Thomas Grisso, Psychological Evaluations in Divorce Custody: Problems, Principles, and Procedures, in Psychology and Child Custody Determinations 
Even those who concede the pitfalls of evaluative criteria might object to the narrow focus of an approximation inquiry in cases in which the child has received inadequate care before divorce. To be sure, if parenting has been so deficient that justification exists for state intervention on grounds of abuse or neglect, then a restructuring of family responsibilities is desirable. ${ }^{74}$ However, the fact that the family is before the court to change its legal status should not, in itself, call for a reassignment of parental roles. In the ordinary case, one parent should not be heard to complain that although the other spouse participated in the child's life before divorce, the quality of that participation was wanting and now warrants restriction.

\section{Applying the Approximation Standard}

Even if the approximation framework is a theoretically superior approach for resolving custody disputes, it is only useful if it can be translated into a rule that courts can apply with reasonable accuracy at reasonable cost. Translating evidence about past parental care and responsibility into a plan for future custody will often be a formidable task that is prone to error. ${ }^{75}$ Moreover, it may be logistically impossible for courts to mirror in the custody arrangement the intricate patterns of parental care and responsibility that existed in the intact family. For example, the custody arrangeinent will usually not reflect the specific division of tasks and decisions that the parents had previously allocated between themselves. Each parent will usually perform all the daily caretaking responsibilities while the child is hiving with him or her.

157 (Lois A. Weithorn ed., 1987). The following factors strengthen the possibility for distortion of the qualitative assessment of parenting and family functioning at the time of divorce. First, the emotional nature of the divorce context can bring out the worst behavior of the parents, so that inferences drawn during this time about their parenting ability and stability in more normal times may be grossly inaccurate. Second, both parents can have incentives to distort information about themselves and the other parent, making it extremely difficult to obtain an accurate picture of family functioning.

74. In other words, the court deciding child custody upon divorce should apply the standard for intervention in an ongoing parent-child relationship that is applied in an abuse/neglect proceeding. Under this analysis, unless parental care was so deficient as to warrant state supervision of the family or removal of the child from parental custody, a qualitative assessment of predivorce parenting should not be relevant to the custody allocation.

75. The approximation framework itself can motivate predivorce behavioral effects that complicate the factual inquiry and increase the risk of error. Parties contemplating divorce in the near future, or simply unhappy with their marriages, might behave in a way that exaggerates their participation in their child's hife. Their purpose can be to extract an advantage on settlement (either a greater share of custody or of assets) or to influence a custody adjudication. This type of predivorce conduct can subtly interfere with parents' inclinations to support each other's involvement in childrearing. I cannot suggest a complete cure for this distortion. However, the incidencc of this behavior could be reduced and its effect neutralized if courts investigate dramatic, otherwise unexplained changes in the level of child care occurring shortly before divorce. By examining parental roles from a long-range perspective and evaluating participation over time, courts will be less likely to give recent behavior undue weight. 
If the proposed framework is to guide custody decisionmaking without excessive enforcement costs, it must characterize predivorce family arrangements by using simplifying categories or rules of thumb to ease the judicial task of applying the rule. For example, three categories can be constructed that roughly refiect various patterns of parental involvement, although necessarily with less accuracy than a more precise description of parental roles would provide. The categories would span a contimuum from a family in which both parents equally share child care responsibility to one in which one parent is uninvolved while the other shoulders most of the burden. In current parlance, the former family's custody arrangement looks like joint physical and legal custody, the latter like sole custody and visitation. A third category, lying between these two poles, would include families with two mvolved parents, one of whoin bears the greater burden of child care responsibility. A family in this third category might have a custody arrangement that is similar to joint legal custody, with the child's primcipal residence beimg with the primary caretaker and secondary residence with the other parent. The actual time allocation between residences would be based on each parent's participation in the child's life before divorce. Thus, a court ordering custody for a family in this group might use a variety of formulas to allocate the child's time between households, designatimg time with each parent as a proportion of the inonth or week. For example, the order might direct that the child live with an actively participating secondary caretaker twelve days a month (or three days a week), while a less involved secondary parent might be awarded physical custody eight days a inonth (or two days a week). ${ }^{76}$ Adjustments to accommodate the child's schedule might be necessary, with coinpensating time allocated durimg the summer inonths. Courts might also explore the areas of authority held by each parent before divorce. Thus, if one parent made all the decisions relating to education, the custody order inight reflect this. ${ }^{77}$ Alternatively, courts could presume shared authority in the typical family and allocate inore specifically ouly if disputes arise.

A skeptic might argue, and I concede, that the approximation framework, implemented as I have suggested, only roughly bases future custody arrangements on predivorce roles. Moreover, even with the simplifying categories, courts imight imisapply the standard. One might fairly ask whether the approximation framework in practice represents any tangible advance over existing custody decision rules. What distin-

76. A more complex approach would involve a rough assessment of the proportion of care given by each parent (e.g., 60/40 to $80 / 20$ ). In my view, although the latter approach is morc precise, its complexity would unnecessarily increase the procedural costs of making the custody determination.

77. A very hard case would be one in which one parent was very involved in decisionmaking but spent little time with the child. 
guishes this approach from other custody frameworks is not that the categories describing outcoines are new, although few states in practice offer the broad range of arrangements available under the proposed framework. Rather, I beheve the approximation criterion differs because it is more likely to direct custody arrangements that maximize the collective interests of all the affected parties. The framework clearly tells courts what counts and what does not in deciding custody claims. If what counts-predivorce involvement in the child's life-provides a sounder base for future arrangeinents than the criteria weighed under other frameworks, then even the rough rephcation of prior roles einbodied in the rule of thumb categories will likely yield inore satisfactory outcoines than will other decision principles. To be sure, error will mevitably result when courts inake the often coinplex evidentiary judgments necessary to determine the correct custody category. The impact of such error is likely to be far less severe, however, than that incurred under other frameworks. Because their essential preimises are flawed, conventional approaches create outcomes that offer less promise for stable and successful custody. ${ }^{78}$

\section{The Symbolism of Approximation}

Resolving the issue of how a child's time will be spent after divorce often involves conflict. ${ }^{79}$ It would be naive to hope that a legal framework can radically alter the essential character of the dispute. Nonetheless, the proposed approximation framework helps to imitigate the adversarial nature of the custody decision in two ways. First, the outcome loses some of its character as a prize to be captured by one parent or the other. ${ }^{80}$ Neither parent loses if both have invested in the relationship with the child. Thus, in the context of the approximation inquiry, the categories that describe custody outcoines take on inore neutral meanings as alternative blueprints, one of which best reflects past relationships. Second, the antagonistic tone of the dispute may be muted because of the nature of the approximation inquiry, which considers more concrete and quantitative factors than do inquiries under current

78. See supra notes $\mathbf{7 2 - 7 3}$ and accompanying text (describing problems with traditional custody proceedings).

79. At a minimum, conflict can come from two sources. First, the anger often associated with marital breakdown is likely to infect the custody decision process. Second, each parent might want more time with the child than the amount available to that parent. Because the parents often cannot enjoy time with the child together after divorce, the child's time must be split between them, resulting in less total time for each parent. See also supra note $\mathbf{7 0}$ and accompanying text (discussing problems arising during custody proceedings).

80. The adversarial nature of custody disputes is not limited to cases of sole custody. Even joint custody cases can assume strong adversarial tones. For example, if one party requests joint custody against the wishes of the other, conflict often arises and "unconscionable bargaining" can result. See Elster, supra note 1 , at 6 \& n.22. 
frameworks. Although, to be sure, parties will dispute who was the more involved parent, inflammatory evidence about each parent's character and about quality and competency of parenting is not useful to the court and can be excluded, reducing. solnewhat the potential for hostile exchange. ${ }^{81}$

The focus under the approximation inquiry on each parent's past care of the child also underscores relational values that are somewhat obscured under conventional custody rules. ${ }^{82}$ Despite rhetoric to the contrary, modern custody law has as much to do with the legal rights of parents as with the welfare of the child. Custody has becoine viewed as a valuable legal entitlement to be won in a fair contest between parties with equal legal claims derived solely from their status as parents. As I have argued, the hiberal premises of the process push the substantive inquiry in a direction that reduces the central importance of the past parental relationship with the child. The influence of tiberal ideology is less pronounced under the approximation inquiry because parental rights are interwoven with notions of care and responsibility. Although each parent might have an equal legal claim to custody at their child's birth, the success of subsequent claims will depend on each parent's commitment and participation during the child's life. ${ }^{83}$ Without sacrificing fairness to parents, approximation fulfills better than other frameworks the rhetori-

81. Moreover, resentment that arises because the custody rule does not adequately consider a parent's past investment in her relationship with her child will be reduced.

82. Professor Katharine Bartlett has argued that traditional custody law expresses an ideal of parenthood that is based on notions of exchange and individual rights. She proposes instead that the law "re-express" parenthood in terms of responsibility and relationship. Katharine T. Bartlett, $R e$ Expressing Parenthood, 98 YALE L.J. 293, 294-95 (1988); see also Bartlett \& Stack, supra note 9, at 34 (joint custody rule emphasizes responsibility rather than rights). Martha Minow has criticized traditional conceptions of family law as being based on individualistic, masculine values while discounting feminine values of care and responsibility. See Martha Minow, "Forming Underneath Everything That Grows": Toward a History of Family Law, 1985 WIS. L. REv. 819, 893-94. Others have commented on the impact of the individual rights' ideology on family law's portrayal of relations between family members. See Carl E. Schneider, Moral Discourse and the Transformation of American Family Law, 83 Mich. L. REV. 1803 (1985) (liberal individualism has diminished the law's "discourse in inoral terms" on family relations); Elizabeth S. Scott, Rational Decisionmaking About Marriage and Divorce, 76 VA. L. REV. 9 (1990) (the importance of the value of commitment in family relationships has been obscured under modern divorce law).

83. This approach is grounded in eonstitutional doctrine. The United States Supreme Court has evaluated the stature of the parental rights of unmarried fathers by analyzing the extent to which the father has assumed parental responsibility and established a relationship with his child. In Lehr v. Robertson, 463 U.S. 248 (1983), the Court stated:

The significance of the biological connection is that it offers the natural father an opportumity that no other male possesses to develop a relationship with his offspring. If he grasps that opportunity and accepts some measure of responsibility for the child's future, he may enjoy the blessings of the parent-child relationship ....

Id. at 262. The Court also eommented that "a natural father who has played a substantial role in rearing his child has a greater claim to constitutional protection than a mere biological parent." Id. at 262 n.18. 
cal promise that custody is about children's welfare rather than parents' rights.

In this Section I have attempted to explain how the approximation approach to custody determination theoretically produces beneficial changes in the custody process. These benefits include mitigation of the adversarial nature of the custody decision and increased emphasis on family relational values. In the next Part, I will support these theoretical and intuitive arguments with a more formal analysis of the approximation approach. Using the basic tenets of bargaining theory, I will demonstrate that the approximation approach is more likely to enhance cooperative rather than adversarial aspects of custody dispute resolution.

\section{III}

\section{Bargaining Theory and Custody Decision Rules}

Most divorce settlements and custody arrangeinents are decided through a process of negotiation between the spouses. Nonetheless, when divorcing spouses bargain "in the shadow of the law," the prevailing legal rules regulating divorce and custody can affect the negotiation process substantially. ${ }^{84}$ Custody negotiation and the goals of custody law have a highly interactive relationship. In the context of divorce, negotiation and bargaining generate unique psychological and economic costs that can negate solne of the benefits the law anticipates froin a preferred custody rule. In turn, bargaining costs are partly a function of the custody rule itself, because divorcing parents will negotiate within the frainework established by the law. This interdependence suggests that a key ineasure of the effectiveness of a custody rule is its mipact on the bargaining process. In this Part, I argue that a custody rule that mirrors the actual preferences of parents will reduce harmful bargaining costs and thereby better realize the goals of custody law.

\section{A. The Character of Divorce Bargaining}

\section{Bargaining Interactions}

Divorce bargaining is complex, particularly when the custody of children is at stake. The range of issues to be resolved, the past and future relationships of the parties, and the role that anger and spite can play result in a bargaining situation that could potentially involve inany different types of bargaining "gaines" or interactions. ${ }^{85}$ When the parties

84. In a landmark article, Robert Mnookin and Lewis Kornhouser demonstrated how substantive divorce and custody rules affect the bargaining process outside the courtroom. See Robert H. Mnookin \& Lewis Komhauser, Bargaining in the Shadow of the Law: The Case of Divorce, 88 YALE L.J. 950 (1979).

85. Game theory is a formal theoretical approach to the problem of resolving conflicts of interest. For two classic treatments of gaine theory, see DUNCAN LUCE \& HowaRd RAIFFA, 
to a divorce settlement agree to a custody arrangement through an interaction that maximizes the benefits for all parties, then the negotiation is analogous to a positive-sum game. ${ }^{86}$ Divorce settlement can also have the character of a zero-sum imteraction, however, when each party battles for a larger share of a finite amount of property and custody. ${ }^{87}$ At its worst, divorce bargaining can diminish or destroy the value of the benefits to be distributed. ${ }^{88}$ Thus, when parents' bargaining over custody damages future family relationships, ${ }^{89}$ the process is analogous to a negative-sum game.

Two aspects of custody disputes create the potential for a positivesum interaction that produces value through cooperation. First, although custody imvolves a finite amount of time and authority to be divided, parents may prefer different amounts. Thus, an outcome that

Games and Decisions: INTRoduction and Critical SuRvey (1957); Thomas C. Schelling, The STRATEgY OF CONFLICT (1963). According to Luce and Raiffa, game theory is based on certain assumptions: that each individual seeks to maximize his own utility; that the various possible outcomes of a particular situation are well specified; that individual "players" have consistent preferences umong these outcomes; and that all players know the preference patterns of the others. LUCE \& RAIFFA, supra, at 4-5. Game theorists acknowledge that some of their assumptions do not refleet the reality of interest-conflict resolution. See, e.g., id. at 5; SchELLING, supra, at 4. These assumptions are relaxed in modern game theory, which focuses on noncooperative games involving players with asymmetric and imperfect information. For a comprehensive treatinent, see ERIC

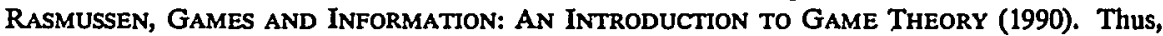
game theory should become increasingly useful in understanding "real life" conflict resolution situations such as divorce bargaining.

86. A positive-sum game can produce value through cooperation. One type of positive-suin game is a pure coordination game in which both parties have the same goal. Charades is an example. In such a game, the process of negotiation involves coordinating mutually consistent expectations rather than accommodating adverse expectations, so that the parties win or lose together. See generally SchelliNG, supra note 85 , at $89-99$ (coordination games). A variant of the pure coordination game can be foumd in problem solving theory. Fisher and Ury popularized "principled negotiation," problem solving that conceives of disputes as problems that can be resolved jointly to mutual advantage and solves any conflicts of interest that arise by einploying fair standards "independent of the will of either side." ROGER FISHER \& WILLIAM URY, GETTING TO YES: Negotiating Agreements Without Giving IN xii (Bruce Patton ed., 1981). For an applieation of problem solving to legal negotiation, see Carrie Menkel-Meadow, Toward Another View of Legal Negotiation: The Structure of Problem Solving, 31 UCLA L. REv. 754 (1984).

87. In a zero-sum game, total wiumings less total losses equals zero. There is no value in cooperation because the players have precisely opposite preferences and there is no outcome that they would both prefer. See MiChaEL BACHARACH, Economics AND THE THEORY OF GAMES 7-8 (1976); LUCE \& RAIFFA, supra note 85, at 85. "[F]or every pair of outcoines if one player prefers the first, the other must prefer the second." BACHARACH, supra, at 8. A zero-sum game is a gaine of pure redistribution; no value is produced or destroyed. See Robert Cooter et al., Bargaining in the Shadow of the Law: A Testable Model of Strategic Behavior, 11 J. LEGAL STUD. 225, 227 (1982).

88. The destructive potential of divorce negotiations was graphieally suggested by a recent film. See The WAR OF THE Roses (20th Century Fox 1989). Using their house as a battleground, the spouses set out to attain their adverse goals, sacrificing everything in the process. In a more realistic setting, assets can be depleted, spouses and children emotionally scarrcd, and future relationships impaired by such adversarial divorce negotiations.

89. As the analysis will demonstrate, the damage can affect both parent-child relationships and relationships between parents. 
maximizes their joint preferences will produce value. Second, what is at stake is not smiply time and authority, but the future relationships between parents and child, the value of which may be either enhanced or dimimished by the bargaining process. In contrast, property settlement and alimony issues, although they have positive-sum aspects, ${ }^{90}$ are more suited to resolution through zero-sum interactions. Because both parties presumably want as large a portion as possible of a finite amount of assets, the potential for increasing value through cooperation is more limited than in custody negotiations.

Although bargaining games tend to be positive-sum because both parties benefit froin the exchange, ${ }^{91}$ this might not be true when divorcing spouses exchange custody for property. ${ }^{92}$ First, such exchanges systematically tend to undermine the financial security of custodial parents and thus, ultimately, of children. ${ }^{93}$ Moreover, in the umique context of divorce negotiation, bargaining costs can spiral, becoming so burdensome as to overwhelm the possibility of a beneficial outcome. ${ }^{94}$ Thus, the prospect for successful resolution can be enhanced to the extent that bargaining over economic issues can be separated from the process of deciding custody. ${ }^{95}$ Combining these issues will tend to highlight zero-sum features of the interaction.

\section{Bargaining Costs and Impediments to Bargaining}

Several kinds of bargaining costs can impede successful divorce settlement. Although all negotiations incur ordinary transaction costs asso-

90. Parties attach preferences and desires for marital assets for reasons other than monetary value. For example, one party might associate idiosyncratic value to particular assets, while the other might have a preference for liquidity. See Robert H. Mnookin, Divorce Bargaining: The Limits on Private Ordering. in The Resolution of FAMILy Conflict 364, 367 (John M. Eekelaar \& Sanford N. Katz eds., 1984). Thus, a cooperative interaction that distributes assets in a way that maximizes the parties' joint imterests will enhance value.

91. Bargaiming games have been called "mixed-motive games" because parties have both common and conflicting imterests. SchelIING, supra note 85, at 88-89. For a discussion of twoperson bargaiming games, see generally LuCE \& RAIFFA, supra note 85, at 114-54. Cooperative bargaining divides the stakes to produce a jomt benefit or surplus. Robert Cooter, The Cost of Coase, 11 J. LEGAL STUD. 1, 17 (1982); Cooter et al., supra note 87, at 227-28.

92. Cf. Scott \& Dedeyn, supra note 3 , at $477-81$ (motliers who strongly desire custody might make financial concessions to obtain it); supra notes 34-35 and accompanying text (equal parental rights to custody miglit give fathers a bargaining advantage over former wives who desire custody).

93. Many women care more about obtaining custody than do men, and might trade away their claims to support and property to imsure getting their children. See Neely, supra note 24, at 177-81 (discussing the trading of clildren for money in divorce proceedings).

94. For a discussion of the unique bargaining costs associated with divorce, see infra notes 10306 and accompanying text.

95. Separation of custody negotiations from bargaining about property and support is a goal that cannot be fully realized, of course; child and spousal support is interwoven with custody, and even property issues sucli as the disposition of tlie family home are linked to custody. What I liope to demonstrate, lowever, is that the tendency to exchange custody for property is at least partly dependent on the applicable custody rule itself. 
ciated with assembling the parties and exchanging information, ${ }^{96}$ dispute settlement negotiations also tend to generate peculiar psycliological and economic costs. In the case of divorce bargaining, these costs are likely to be especially onerous and to create substantial impediments to cooperative settlements. ${ }^{97}$ Divorce bargaining is costly in large part because of the psychological turmoil that often accompanies marital breakdown. In this stressful environment, any interaction between spouses can intensify feelings of anger, rejection, guilt, resentment, and frustration. ${ }^{98}$ These emotions often negatively influence bargaining behavior, and therefore reduce the prospects for a satisfactory agreement. ${ }^{99}$ The fallout of the parents' stress is also likely to impose psychological costs on children. ${ }^{100}$

These general psychological costs multiply if one or both parties are motivated by spite. Although spite occasionally motivates behavior in other bargaining situations, ${ }^{101}$ it is a familiar aspect of divorce negotia-

96. According to Coase, these transaction costs include the time and inoney required "to inform people that one wishes to deal and on what terms, to conduct negotiations leading up to a bargain, [and] to draw up the contract," among other things. R.H. Coase, The Problem of Social Cost, 3 J.L. \& Econ. 1, 15 (1960).

97. This is so in part because of the past intinacy and estrangeinent of the parties and in part because for some couples the subject of the dispute, custody and property, is a substitute for a larger battle. See Andre P. Derdeyn, Parental Anger, 29 AM. J. ORthopsych1atry 116 (1983).

98. Both spouses experience many forms of stress during the divorce process, including guilt, humiliation, anger, and diminished self-worth. See Kenneth Kressel et al., Professional Intervention in Divorce: The Views of Lawyers, Psychotherapists, and Clergy, in Divorce AND SEPARATION: CONTEXT, CAUSES, AND CONSEQuenCES 246, 256-57 (George Levinger \& Oliver C. Moles eds., 1979). The stress can be caused by the rapid cliange in life circunstances, the nonmutuality of the divorce decision, and/or the distress of separation from the spouse. Id.

99. Robert Mnookin describes how the emotional distress of divorce impairs bargaining belavior. See Mnookin, supra note 70 . The assumption that bargaining parties can make rational, self-interested judgments and aceurately assess their preferences is questionable in the divorce context. Parties might be unable to negotiate at all, or inight agree to terms they later regret. See id. at 367-68. Mnookin advocates private ordering, "the process by which the parties theinselves decide what the consequences of divorce should be," id. at 365, but concludes that safeguards are necessary to protect a teinporarily incapable divorcing spouse froin exploitation by the other during this transition period, id. at 369-70. Solne bargaining dynamics that are typical in the postseparation emotional setting lead to unsatisfactory settlements. One involves a guilty spouse who wishes to end the marriage and is ready to inake great concessions. The problein is coinpounded when slie bargains with an angry spouse who esealates deinands, motivated by feelings of anger and humiliation. A second pattern consists of an aggressive initiator of the separation who negotiates with a spouse willing to accept any terms because of diminisled feelings of self-wortl. Kressel et al., supra note 98 , at 256 . These autlors observe that passivity in negotiating can result in an unsatisfactory settlement. See id. at 260.

100. Many observers have commented on the psychological costs to clildren of the adversary process. See, eg., Elster, supra note 1, at 1-2; Robert E. Einery, et al., Divorce, Children, and Social Policy, in 1 Child Development Research and Social Policy 189, 209-10 (Harold W. Stevenson \& Alberta E. Siegel eds., 1984); Elizabetl S. Scott \& Robert Einery, Child Custody Dispute Resolution, in Psychology AND Child Custody Determinations, supra note 73, at 24.

101. See Arthur A. Leff, Injury, Ignorance, and Spite-The Dynamics of Coercive Collection, 80 YALE L.J. 1, 18-27 (1970) (describing spite as one factor contributing to bargaining breakdown in debtor/creditor disputes in which the outcone of adjudication is clear). 
tions. ${ }^{102}$ Spiteful conduct is peculiarly costly because the actor is not constrained by rational self-interest. The spiteful party knows that his conduct is costly to himself as well as to his opponent but is willing to pay a price for the gratification of inflicting injury and defeating his opponent's prospects for a satisfactory outcoine. ${ }^{103}$ Spite thus exacerbates bargaining costs, greatly enhancing the likelihood of a negativesuin interaction.

Strategic behavior, in the form of threats, bluffs, or other opportunistic conduct, is another costly impediment to settlement. This behavior is a part of many adversarial negotiations ${ }^{104}$ and certainly is common in divorce contests. For exainple, a parent who is mdifferent to having custody might claim otherwise, presenting his spouse with the choice of relinquishing property or testing the threat to hitigate custody. Such a threat can be very effective in the not-unusual case in which the parent who is the target of the strategic behavior strongly desires custody and is risk-averse about the uncertainty of adjudication. Strategic behavior generally mcreases the costs of bargaining; ${ }^{105}$ because of the volatile enotional setting, this effect is magnified in divorce negotiations. Unnecessary transaction costs are incurred and psychological costs mount, the latter falling disproportionately on the party who is the target of the maneuvers. In this situation, patterns of cooperation are likely to be replaced by reciprocal retaliation. ${ }^{106}$ Although the parties might ulti-

102. This is due to the intense emotional distress associated with divorce. The period following separation has been described as a crisis stage in which the parties experience feelings " "both natural and nasty." "Mnookin, supra note 70, at 368 (quoting I. RICCI, MOM's HousE/DAD's House 75 (1980)). One observer commented that " this is the worst possible time to make any permanent decisions-especially legal ones. Thinking and believing the worst about each other is one of the chief hazards of this stage . . . " ' Id. at 368-69 (quoting I. RICCI, MoM's House/DAD's House 70 (1980)).

103. See Cooter et al., supra note 87 , at 239 (defining spite as one party's willingness to accept a less favorable result in order to impair the opponent's outcome). Spite can have the effeet of artificially changing preferences and reducing the possibility of a cooperative outcome. For example, consider a couple, $A$ and $B$, whose respective preferences for custody are equal sharing. An agrecment that allocates custody in this way will maximize the joint benefits of custody. Nevertheless, if $B$, motivated by spite, decides that depriving $A$ of custody is worth more than sharing custody, then a conflictual resolution is imevitable.

104. Menkel-Meadow, supra note 86 , at 775-77 (criticizing the conventional literature on negotiation strategies for assuming umiversal applicability of the "stylized ritual of offer/response, counteroffer/counterresponse," id at 777); see also Mnookin \& Kornhauser, supra note 84, at 973 (arguing that opportumities for strategic behavior exist, in part, because of uncertainty about the other side's preferences and about the outcome of litigation).

One feature of divorce bargaining tends to mitigate strategic behavior. Because parties in this context know each other well and can be expected to be more familiar than most bargainers witl each other's preferences, they can be better able to evaluate bluffs and distinguish serious from strategic threats. However, spite can distort preferences and make such evaluations unreliable.

105. For a discussion of the costly impact of strategic behavior on bargaining, see Cooter, supra note 91, at 17-18.

106. Parties bargaining about divorce are like players in a repeated-interaction game. The responses of such players are contingent on eacl otlier's actions. See ANATOL RAPOPORT \& 
mately reach agreement despite strategic behavior, the benefits of cooperation are lost.

\section{Custody Outcomes and the Costs of Bargaining}

The success of custody negotiations, in both the short and long term, is determined in important ways by the extent to which bargaining costs are contained. A satisfactory agreeinent is most likely to emerge if cooperative patterns of interaction are reinforced and conflict is cabined. By the same token, if costs mount excessively, not only will the process be burdensome but a less-than-optimal outcome becoines more likely. Any inclination of parties to cooperate in this often unstable environment can be transformed by strategic or spiteful conduct into a destructive retahatory exchange. Ultimately the tenuous cooperative pattern breaks down, resulting in either conflictual negotiation or litigation.

In several ways, impediments such as spite or strategic behavior can result in bargaining failure. Parties can imisinterpret real and strategic threats and otherwise misjudge each other's intentions. A spiteful party might negotiate recklessly, purposely risking bargaining breakdown to pumish the other spouse. The result is the loss of the optimal outcome of bargaining: an agreement by which the party who values the entitlement most receives it and the parties share the joint benefits of the move from the less valued to the more valued use. ${ }^{107}$ Moreover, the failure to reach agreement adds the substantial costs of adjudication. In contrast to parties negotiating im other contexts, divorcing spouses cannot walk away when bargaining fails; they must resolve the dispute in court. ${ }^{108}$

The long-term effects of bargaining are even more inportant. Because of the link between the bargaining process and the goals of custody law, cooperative interactions are uniquely beneficial and conflict is uniquely destructive in this negotiation setting. If custody is decided through cooperative dealing in which bargaining costs are contained, future family relationships can be enhanced in important ways. Not only is the resnlting agreement likely to yield a mutually satisfactory arrangeinent, but the stage is set for future coordination and conimunication between the parents. By the same token, because of the parties' ongoing relationship, the effects of substantial bargaining costs also endure well

ALbert M. Chammah, Prisoner's Dilemma: A Study in Conflict and Cooperation 67-71 (1965) (developing a mathematical model accounting for reciprocal patterns of cooperation and conflict that emerge and are reinforced by a lock-in effect). If one party uses strategic threats or engages in spiteful conduct, the other will often retaliate, setting off a series of reciproeal hostile exchanges that can be self-propelling. Id. at 134.

107. Cooter challenges the assumption of the Coase Theorem that bargaining parties will agree to an efficient outcoine in the absence of transaction costs. According to Cooter, Coase's optinistic assumption ignores the problem of strategic behavior. Cooter, supra note 91, at 14-19.

108. Settlement negotiations are a form of bilateral monopoly in which neither party has any alternative bargaining partner. 
beyond the custody decision. Conflictual interactions often result in lingering psychological and economic detriment that undermine the benefits of future custodial arrangements. The harmful effects of divorce on children are caused primarily by reduced contact with one parent, conflict between the parents, and by economic deprivation. ${ }^{109}$ Although these detrimental effects do not derive solely or even primarily from the process of deciding custody, the costs of this process can exaggerate the destructive psychological and economic impact of marital dissolution on children. Anger and bitterness generated in conflictual negotiation or adjudication can poison the prospects of future cooperation between parents. The parties can continue the conflict, or the loser in the custody dispute can withdraw. Either outcome reduces the prospects for stable family relationships in the future; both the relationship between parents and parent-child relationships are imipaired by stressful, angry custody battles.

\section{B. Custody Decision Rules and the Preferences of Parties}

Because bargaining in the volatile context of divorce can destroy the benefits of future custody, a decision rule that contains bargaining costs furthers the substantive goals of custody law. Toward this end, the optiinal rule would allocate legal entitlement to custody so as to reflect the actual preferences of the parties. For parties who are inclined to interact cooperatively, such a rule would reduce the incentive for them to bargain about custody at all. These parties have nothing to exchange because the law gives to each the ainount of custody desired. If the rule reduces the incentive to bargain, the costs associated with bargaining behavior are also reduced.

A rule that promotes cooperative agreenent about custody without bargaming is particularly desirable in this context. In other bargaining settings, as the Coase theorem demonstrates, the initial placement of the legal entitlement does hittle to impede an efficient bargaiming outcome. ${ }^{110}$ This is not so in the unstable context of divorce negotiations because the dehicate process of trading custody rights holds the potential for generating punishing costs. To be sure, even if the decision rule tracks their preferences precisely, sone parties will engage in uncooperative behavior

109. For a comprehensive discussion of social science research on the impact of divorce on children, see generally EMERY, supra note 45, at 33-70.

110. Accordimg to the Coase theorem, under specified conditions parties will bargain to an efficient outcome so that the entitlement will be held by the party who values it more. This outcome occurs because the party who values the entitlement less, if he fails to trade it, forgoes the value that the party who values it anore would trade in exchange for the entitlement. Thus, regardless of how the entitlement to custody is allocated, the theorem predicts that the parties will bargain to an outcome in which their actual preferences for custody are satisfied. See Coase, supra note 96, at 5, 8 (illustrating the theorem's operation). 
out of spite or as part of a strategic plan. Even in these situations, however, a preference-backed rule will reduce costs because it will reveal to both parties the simple fact that there is nothing to trade. Even if bargaining fails altogether, costs are minimized in that the adjudicated outcome tracks the parties' joint preferences for custody and is thus, by definition, efficient. ${ }^{111}$

A rule that awards custody based on the actual preferences of the parties benefits the child as well. Because the rule reduces the destructive costs of resolving custody disputes, it will reduce short-term stress and enhance the opportunity for uninpaired parent-child relationships in the postdivorce setting. Moreover, allocations reflecting actual preferences are likely to be more stable because satisfied parents will be less motivated to seek different arrangements. Thus, if the custody rule tracks parents' preferences, children also will reap both short-term and longterm benefits.

A skeptic might concur that custody decisionmaking would be improved if the decision rule could allocate custody according to parental preference, but object that no legal rule can accomplish this goal. Thus, the presumption underlying the best interests standard and the joint custody rule, that both parents value custody equally, is as sound as any other, although perhaps often inaccurate. ${ }^{112}$ This response, however, neglects the key significance of past parental roles in shaping preference for custody. In Part II, I argued that the best gauge of the value each parent places on custody is that parent's role in the child's life during marriage, a contention that is supported both by empirical evidence and by common sense. ${ }^{113}$ To be sure, past parenting roles will not accurately reflect each parent's preference for custody in every case. Some parents genuinely prefer inore or less custody than their prior relationship would indicate. But if, in general, parents' roles in the intact family more accurately reflect preferences about custody than alternative characterizations (such as equal preference), then a corresponding decision rule will go far to reduce bargaining costs and enhance the benefits of the process for the family.

111. Robert Cooter has demonstrated that the Coase Theorem provides an incomplete account of the implications for bargaining of the placement of legal entitlements because it optimistically presumes that the parties will bargain to agreement. The theorem does not eontemplate that because of strategic behavior (or spite) the parties might not rcach agreement. In this situation, Cooter argues, the law's function should be to minimize the eosts of strategic behavior and bargaining breakdown. See Cooter, supra note 91, at 17-20.

112. This presumption does not, of course, apply to a primary caretaker rule.

113. See supra Section II.A.2. 


\section{The Effects of Alternative Decision Rules on Custody Bargaining}

\section{Parental Preference and Bargaining Under Alternative Rules}

If predivorce roles are the best indicators of parental preference for custody, then conventional custody frameworks distort parental preference. The best interests standard and the rule favoring joint custody err in presuming that parents generally have equal preferences for custody. ${ }^{114}$ In contrast, a primary caretaker preference generally offers to one parent more time and responsibility than she prefers and diminishes the role of the secondary caretaker parent to that of a "visitor," offering to him less time and responsibility than he might prefer.

If the background rule distorts parents' preferences, the process and outcome of bargaining can be affected in several undesirable ways. In the process of reassigning entitlements in the unstable bargaining setting, even parties who are initially inclined toward cooperative settlement can impose costs on one another that lead to conflict and noncooperation. When parents are motivated to exchange custody rights for property to achieve a satisfactory custody outcome, zero-sum features of the negotiation become more prominent because both parties presumably would like a settlement that maximizes property holdings. Moreover, such an exchange will result in an unequal property distribution-an outcome that usually threatens the child's future economic welfare.

Because conventional rules misconstrue parental preference for custody, they promote strategic and spiteful behavior by any party who receives a "wimdfall" legal entitlement that exceeds his preference. For example, consider the effect of a rule that presumes that the parties have an equal preference for custody on the negotiations between a primary caretaker and her husband. These parties, who have asymmetrical preferences for custody, will also have asymmetrical stakes in a prospective adjudication. The husband, who values custody less, will have less to lose than the wife if negotiations break down and custody is resolved by itigation. ${ }^{115}$ This is because what is at stake-each parent's relationship with the child-represents a more modest investment for the husband than for the wife. In contrast, for the wife, successful litigation means

114. Although the formal best interests rule announces that both parents have an equal claim to custody, the courts applying that standard probably continue to favor mothers. See supra Part I. Under a joint custody rule, parents have equal claims to $50 \%$ custody. For a discussion of einpirical data indicating that mothers typically have prinary responsibility for child care, and thus are inore likely to desire custody than are fathers, see infra Section IV.A.1.b.

115. Note that this response is not based on psychological risk aversion contemplating an uncertain outcome but on an assessment of the predicted utility of adjudication versus settlement. The certainty of the rule should not affect the response. For example, a primary caretaker father would respond in this way under a clear rule favoring mothers. See infra text accompanying notes 125-26. Observers have generally attributed this reluctance to litigate custody to risk-aversion in the face of uncertainty. See Mnookin \& Kornhauser, supra note 84, at 950. 
continuing a substantially similar relationship with her child-a inodest gain over her existing entitlement. ${ }^{116}$ The husband, on the other hand, anticipates a significant gain from his ex ante position should he win through adjudication. He will possess a valuable legal right, measured by the extent to which the entitlement exceeds his preferred amount of custody, which he can later trade to the wife who values it more. ${ }^{117}$ Thus, the expected payoff for winning and losing in court is different for each parent. This imbalance confers a significant strategic advantage on the father, increasing the temptation to engage in threats, bluffs, and holdout behavior. ${ }^{118}$ Moreover, if he is inclined to behave spitefully, the legal advantage provides the opportunity for punishing his spouse.

The approximation framework is superior to conventional frameworks as a background bargaining rule because it distributes entitlements to custody im a way that is more hikely to track parental preferences. There is less likelihood of an asymmetry in the parties' choices between litigation and settlement. Although they have different stakes in custody, the rule directs an outcome that mirrors that difference. For this reason, the framework encourages cooperative negotiations and discourages strategic or spiteful behavior, thus enhancing the possibility that parties will reach a cooperative agrecinent about custody independent of their bargaining over property rights.

\section{Precision as a Measure of Background Bargaining Rules}

Another important, and inore conventional, measure of the usefulness of different legal formulations as background rules for bargaining is precision. ${ }^{119}$ A precise rule promotes successful bargaining because it suggests an obvious basis for agreement-some apparent solution to the parties' differences that can be distinguished from a continuuin of possibilities. ${ }^{120}$ Such a rule serves this function by signalling clearly the outcome of adjudication, thus encouragiug settlement and thereby reducing bargaining costs. A bright-line rule favoring jomt custody, for example,

116. For a primary caretaker mother, successful litigation under a joint custody rule means obtaining exclusive custody by persuading a judge that joint custody is detrimental to the child's welfare.

117. "Excess" custody could be a loss to the father, of course, if he were unable to trade it to the mother. As long as she wants custody, however, the entitlement will be valuable to him.

118. If this couple bargains under a joint custody rule, the magnitude of the loss and gain that each spouse contemplates is less dramatic. In this framework, however, the asymmetrical stakes make adjudication even less attractive for the wife because her loss and the husband's gain are more certain.

119. See Mnookin \& Kornhauser, supra note 84, at 978-80.

120. Thomas Schelling argues that the challenge for bargaining is to coordinate expectations. This coordination is facilitated if there is some focus for agreement or suggestion contained in the situation itself. Examples of this phenomenon include the tendency of bargains to express outcomes in round numbers, to split the difference, to look to precedent, and to agree to a 50/50 division. SCHELLING, supra note 85 , at 67-74. 
encourages parties bargaining in its shadow to agree to joint custody. In contrast, a broad standard, because it offers little guidance to bargaining parties about the probable judicial resolution of the dispute, does little to facilitate agreeinent. Mucl criticisin of the best interests standard has focused on this deficiency. ${ }^{121}$ Because the outcoine of adjudication is uncertain, tlie standard encourages strategic beliavior and prolongs negotiation. Its imprecision contributes to increased bargaining costs and to the risk of uncooperative outcoines or bargaining failure.

An imprecise rule such as the best interests standard imposes particularly heavy costs on the party who is inore risk-averse about the outcoine of adjudication. If divorcing spouses have asymmetrical stakes in the outcome, they miglit also differ in their risk aversion. The party who has a greater stake in continuing her parenting relationship might be inore reluctant than her spouse to subject the custody decision to the uncertainty of judicial determination even if she actually faces a sinaller risk of losing custody than does her spouse. ${ }^{122}$ Research findings indicate that decisionmakers anchor choices in the status quo and tend to be riskaverse about protecting existing endowinents. Moreover, losses loom larger than gains when both are equally likely. Therefore, individuals will weigli the loss of an existing endowment more heavily than foregone gains of equal expected value. ${ }^{123}$ A primary caretaker parent conteinplating hitigation under the best interests standard miglit see tlie risk as the loss of an existing endowment-the relationship with the child. The less mvolved parent, on the other hand, might perceive adjudication of custody as an opporturity to gain a new endowment. Thus, lie is likely

121. See Mnookin \& Kornhauser, supra note 84 , at $977-80$. The best interests standard announces that any relevant variable can determine outcoine, and thus provides little guidance.

122. Even though the actual risk that inothers will lose custody is surely less than $50 \%$, the uncertainty of outcoine combined witl the magnitude of the loss makes it appear greater than it is.

123. This response is known as the "endowment effect," a theory developed by Richard Thaler to describe the inertia introduced into the consumer-choice process because people place a relatively high value on things they already possess-their endowments. Richard Thaler, Toward a Positive Theory of Consumer Choice, 1 J. ECON. BEHAV. \& ORGANIZATION 39, 44 (1980); see also Riclard H. Thaler, Illusions and Mirages in Public Policy, PuB. INTEREst, Fall 1983, at 60, 64 (discussing empirical evidence supporting the endowment effect theory). The endowinent effect is based on "prospect theory," which posits that decisionmakers evaluating gains and losses systematically deviate from ideals of rational choice because they view "outcoines as gains and losses, rather than as final states of wealth or welfare." Daniel Kahneinann \& Amos Tversky, Prospect Theory: An Analysis of Decision Under Risk, 47 EconometricA 263, 274 (1979). This behavior is contrary to that predicted by rational choice theory-that clioices are made so as to maximize aggregate utility. See id. at 277-80; see also Daniel Kahneinann \& Amos Tversky, Choices, Values, and Frames, 39 AM. Psychologist 341, 343-44 (1984); Robert E. Scott, Error and Rationality in Individual Deeisionmaking: An Essay on the Relationship Between Cognitive Illusions and the Management of Choices, 59 S. CAL. L. REv. 329 (1986) (discussing prospect theory in light of the endowinent effect); Amos Tversky \& Daniel Kahneinann, The Framing of Decisions and the Psychology of Choice, 211 SCIENCE 453 (1981) (exanining subjects' evaluations of clioices and concluding that the inanner in which a choice is presented (as a loss or a gain) will affect the perceived risk). 
to view the prospect of litigation more affirmatively ${ }^{124}$ - a psychological stance that conveys a strategic advantage. In practice, this bargaining dynamic is likely to exaggerate the skew toward unequal economic settlement, disadvantaging motlers and, ultimately, cliildren. Thus, the psychological response of loss aversion combimes with the reatistic assessment of asymmetrical stakes in the outcome to reinforce the tendency of mothers facing adjudication under the best interests standard to settle out of court.

Althougli a precise custody formulation will generally function better than a broad standard in reducing bargaining costs, the benefit will be lost unless the rule also reflects parental preference for custody. Parties bargaining in the shadow of a precise rule that distorts their preferences will either exchange entitlements to reach a satisfactory agreement or agree to an arrangement that reflects the rule but not their preferences. I have described the costs of the former response. The latter can be just as costly. For example, a couple bargaining under a joint custody presumption miglit agree grudgingly to joint custody because of a reluctance to excliange assets, a lack of assets to exchange, or because they conclude that they can tolerate the arrangement. If this happens, the negotiated arrangement can be unstable, leadimg to rehitigation, withdrawal from the custody relationship, ${ }^{125}$ or "drift" to a more satisfactory arrangeinent. ${ }^{126}$

The approximation framework will function better than the conventional alternatives as a background rule for custody negotiation because it offers maximum precision with minimal distortion of parental preference. To be sure, this approach offers a less precise guide to bargainers than would a briglit-line joint custody preference, both because of the somewhat complex mquiry and because of the range of possible out-

124. Moreover, the less risk-averse party might be more optimistic about the outcome of litigation, which can contribute to the breakdown of bargaining. Cf. RICHARD A. POSNER, ECONOMIC ANALYSIS OF LAw 434-40 (2d ed. 1977) (arguing that a dispute is more likely to be resolved by litigation if both parties are optimistic about the outcome); John P. Gould, The Economics of Legal Conflicts, 2 J. LEGAL STUD. 279 (1973) (arguing that risk preferrers will gamble, that is, will go to court). Uncertainty in the background rule could promote optimism in the party who has less to lose.

125. Fathers in traditional arrangements often withdraw from the relationship with their children, in part out of dissatisfaction with their minimal role as "visitors." See supra note 27 and accompanying text.

126. These parents, for the reasons suggested, might agree to joint custody and later implicitly acknowledge their preferences through their conduct. See Mnookin et al., supra note 34, at 65.67 (comparing legal outcomes with children's actual residence patterns). If this were routine and predictable, the primary parent could avoid bargaining costs by agreeing to joint custody, knowing that eventually the preferred arrangement would emerge. However, uncertainty about this outcome, because of spite or conflict generated by the unaccustomed roles, will reduce its impact on bargaining. The conflict generated by hostile bargaining or litigation inay impede the natural course of role realignment. 
comes. ${ }^{127}$ As experience with joint custody suggests, however, greater precision has a cost. ${ }^{128}$ Given the variety among families, a clear rule preferring any one custody arrangement will promote an outcome that distorts many parents' preferences. The relative complexity and imprecision of the approximation imquiry is necessary to promote satisfactory arrangements. At the same time, this framework is considerably more precise than the best interests standard, substantially narrowing the inquiry and inore clearly signalling the outcome of adjudication.

Ultimately, the effects of imprecision under the approximation framework are likely to be modest. A court might err in measuring the prior parental role but is unlikely to deprive an involved parent of custody altogether, as can happen under the best interests standard. Thus, the magnitude of the prospective loss associated with hitigation is lessened, and the impact on bargaining of risk aversion will be inoderate.

\section{Bargaining and Substantive Custody Goals}

I return from a different vantage to a theme introduced at the beginming of this Part-the interdependence of custody bargaining and the substantive goals of custody law. An adequate custody rule both expresses the law's substantive pohicy goal of facilitating arrangements that are beneficial to children and functions as a background rule that encourages cooperative settlement with minimal costs. Current legal frameworks are madequate because they fail in one regard or the other. A clear joint custody rule serves as an efficient bargaining rule in some regards, but it may tend to proinote unsuitable custody arrangements, thus distorting the law's policy goal. The best interests standard, on the other hand, accurately mirrors the law's policy goal, in theory. In practice, however, its serious deficiency as a background bargaining rule severely imipedes the capacity of the best interests standard to accoinplish the substantive goal-custody arrangements that promote the child's welfare. The approximation standard is more likely than is either conventional rule to function satisfactorily in both respects. This framework extracts from the multivariate, discretionary best interests standard the factor that best predicts successful custody arrangements. In this way it offers greater guidance as a background bargaming rule thian the best interests standard. At the same time, it signals adjudication outcoines to bargamers and only distorts the law's policy goal when custody based on

127. For a discussion of the imquiry under the approximation framework, see supra text accompanying notes 76-77.

128. In general, because of its simplicity, a precise background rule will tend to distort the law's policy goals. See Scott \& Derdeyn, supra note 3, at 462-64. See generally Isaac Ehrlich \& Richard A. Posner, An Economic Analysis of Legal Rulemaking, 3 J. LEGAL STUD. 257 (1974) (contrasting the costs associated with clear rules with those associated with broad standards). 
prior parental roles is not the arrangement that reflects the child's best interests.

\section{IV \\ The INFluence of Custody LaW on the Evolution OF GENDER NORMS}

Legal rules can be examined not only in terms of their efficiency in resolving disputes between parties, but more broadly as expressions of societal values and instruments of social change. In this Part, I will look at custody law im this light. Some scholars have argued that custody law could facilitate a transformation of gender role ideology by encouraging spouses to share doinestic and employinent roles. Katharine Bartlett and Carol Stack, for example, argue that a joint custody preference will promote desirable ideological and attitudimal change by expressing commitinent to egalitarian norms. ${ }^{129} \mathrm{I}$ am sympathetic to this goal but skeptical that the legal tool of custody law can accomphsh the task. Such optimisin fails to account adequately for the continumg pervasive influence of preexisting roles on attitudes, behavior, and the character of family relations. Moreover, in general, the law functions ineffectively in the regulation of intricate ongoing family relationships. Thus, a joint custody rule, which seeks to reform the ideology of gender roles by directing reluctant parents to share responsibihty for their children, is likely to disappoint expectations. On the issue of custody, the reformative potential of the law is limited to supporting parents who have sliared responsibility during inarriage and sigualling that an investment in parenting will not be lost.

\section{A. The Process of Family Role Change}

I do not want to review extensively the familiar arguments favoring the egalitarian restructuring of family roles. Although some controversy continues to surround this issue, few would dispute that traditional parental roles, and the resultimg economic dependence of women on inen, are maladaptive in a world im which a substantial percentage of marriages end in divorce. ${ }^{130}$ The trend toward interchangeable work and family roles offers the promise of greater economic security for woinen

129. Bartlett and Stack argue that the symbohc expressive function of law influences ideological change. Drawing on the analogy to civil rights law, they suggest that the law can compel certain behavior, which then becomes institutionalized and routine, eventually effecting attitudinal and normative change in those initially resistant to the law. See Bartlett \& Stack, supra notc 9, at 28-35.

130. A great deal has been written about the economic disabilities of divorced women, particularly those with children. See, e.g., EMERY, supra note 45, at 126-27 ("Women who enter or re-enter the workforce after divorce have sacrificed earning potential by assuming the homemaker role," id. at 126); LeONORE J. WeITZMAN, The Divorce Revolution 323-29 (1985) ("For most women and children, divorce mcans precipitous downward mobility," id. at 323). 
and children; ${ }^{131}$ it also improves the prospects for a stronger paternal presence after divorce. Moreover, egalitarian parental roles offer numerous intangible benefits. ${ }^{132}$ By challenging categories that define particular human qualities and functions by gender, interchangeable roles expand the range of experience of both men and women. ${ }^{133}$ Advocates might argue that a joint custody preference could promote desirable changes im gender ideology by conveying a symbolic message about how men and women should participate in their children's lives. ${ }^{134}$ This

131. If women and men left marriage with comparable work experience and earning capacity, much of the economic hardship that custodial mothers and their children now experience would be alleviated. Currently available remedies designed to compensate upon divorce for the disparity in earning capacity between men and women are conceded to be inadequate, and no corrective measure is likely to be very satisfactory. At the heart of the problem is an unexamined value conflict in divorce policy. In theory, divorce law seeks to protect the dependent wife from economic harm incurred because she fulfilled her expected maternal role. Burdening the husband with onerous support obligations, however, conflicts with the modern legal norm that endorses each spouse's freedom to end the marriage and pursue fulfillment through other relationships.

132. Studies have found that women who fill multiple roles experience greater satisfaction than women whose full-time occupation is working in the home and caring for children. See JEsSIE BARNARD, The FUTURE OF MARRIAGE 46-47 (1982) (describing positive mental health effects of work for married women); Cynthia F. Epstein, Toward a Family Policy: Changes in Mothers' Lives, in The Changing American Family and Public Policy 157, 165-69 (Andrew J. Cherlin ed., 1988) (women employed outside the home are likely to benefit psychologically from the experience if the result is that they feel they have more control of their lives); Ronald C. Kessler \& James A. McRae, Jr., The Effect of Wives' Employment on the Mental Health of Married Men and Women, 47 AM. SOC. REV. 216, 219-23 (1982) ("[E]mployment is associated with improved mental health among women whose husbands share childcare," id. at 220). But see Paul D. Cleary \& David Mechanic, Sex Differences in Psychological Distress Among Married People, 24 J. HealTH \& Soc. BEHAV. 111, 116 (1983) (in households in which the mother works outside the hoine, a positive correlation exists between depression in women and the number of minor children).

In a study of men and women law school graduates, David Chambers found that women who have children and who accommodate career and family responsibilities reported greater satisfaction in balancing their careers and families than did men. David L. Chambers, Accommodation and Satisfaction: Women and Men Lawyers and the Balance of Work and Family, 14 LAW \& Soc. INQUIRY 251 (1989). This group of women were also more satisfied than career wolnen without children, suggesting that significant investment in both work and family roles inight promote maximum satisfaction. Id. at 273-76. This may be true despite the fact that employed women are also burdened with more domestic responsibilities than employed men. See JOSEPH H. PLECK, WORKING WIVES/WORKING HUSBANDS 15 (1985). In addition, Chambers found that attorney fathers, although not less satisfied with their work per se, were less satisfied than were attorney mothers with the balance of their family and professional lives and generally expressed less overall career satisfaction. Chambers, supra, at 273-76. Men were also far more hikely to work in large law firms, work settings which, although prestigious and financially rewarding, are also among the least accommodating to participation in family life.

133. Joan Williams, in a persuasive critique of the perspective of "difference" feminisin, has argued that not only the functions but also the personal traits characterized as masculine and feminine are shaped by socially constructed gender roles. Following this reasoning, there is no reason to believe that fathers inherently have less capacity to nurture and to connect in relationships, qualities that are culturally defined as feminine. Likewise, mothers can be powerful, competitive, and independent, although these are currently viewed as predominately male traits. Williams, supra note 36 , at $840-43$.

134. Bartlett and Stack, supra note 9, at 28 \& n.92. 
expectation, however, underestimates the influence of entrenched gender norms on individual behavior and attitudes. Recent changes in parental roles have been inore superficial than is apparent, and the sources of resistance to inore fundamental change are deep. Thus, efforts to effect change through direct legal inamipulation of family relationships will be costly.

\section{The Continuing Influence of Traditional Parenting Norms}

On one level, the roles of men and women in inarriage and in the workplace have undergone extraordinary change in the past fifty years. ${ }^{135}$ Nonetheless, the inagnitude of change should not be exaggerated. The current situation is inost accurately described as a period of normative pluralisin in which no shared ideal defines family and work roles. Attitudes fall along a continuum from those who continue to support traditional, highly differentiated gender roles as essential to family welfare at one pole, to those who endorse fully interchangeable parental roles at the other. ${ }^{136}$ Moreover, the moveinent of woinen into the workforce sends a misleading signal about both attitudinal and behavioral change. Indirect evidence indicates that men and women both still regard a woman's maternal and doinestic roles as central to her identity, requiring subordination of other pursuits. ${ }^{137}$ These attitudes are reflected in practice; employed women continue to bear the primary responsibility for rearing children. In general, traditional gender norms continue to have a pervasive influence on behavior and attitudes, inhibiting inovement toward shared family roles.

135. In 1940 only $9 \%$ of women with preschool children worked outside the home. See Jacqelynne S. Eccles \& Lois W. Hoffman, Sex Roles, Specialization and Occupational Behavior, in 1 Child Development Research aNd Social Policy, supra note 100, at 367, 368. By 1985 that number had risen to $52 \%$. Glenna Spitze, The Data on Women's Labor Force Participation, in WOMEN WorkING 42, 44 (Ann H. Stromberg \& Shirley Harkess eds., 2d ed. 1988).

As for women's preferences, a 1985 Roper poll reported that $45 \%$ of women interviewed would prefer to stay home and care for the house and family, whilc $51 \%$ would prefer to work outside the home. The Roper Org., 1985 Virginia Slims Survey 67. The percentage of women who would like to be married with children and have a full-time job was $43 \%$ in 1987. 1987 Gallup Poll Survey 252G.

136. In general there has been a trend toward increasingly egalitarian attitudes about gender roles. See generally Arland Thornton, Changing Attitudes Toward Family Issues in the United States, 51 J. MARRIAGE \& FAM. 873 (1989). There is some evidence, however, that indicates that both men and women express more egalitarian attitudes about gender than their behavior suggests. See Sharon K. Araji, Husbands' and Wives' Attitude-Behavior Congruence on Family Roles, $39 \mathrm{~J}$. MARRIAGE \& FAM. 309, 310 (1977) (with respect to husband-as-provider and wife-as-homemaker, egalitarian role behavior lagged behind egalitarian role attitudes). The percentage of people who endorse fully egalitarian roles is very small. PLECK, supra note 132, at 75-76.

137. See Rita J. Simon \& Jean M. Landis, The Polls-A Report: Women's and Men's Attitudes About a Woman's Place and Role, 53 PuB. OPINroN Q. 265, 272 (1989) (a majority of those polled answered that a woman should put marriage and family ahead of her career, including quitting her job to relocate if her husband.gets a better job). 


\section{a. Women in the Workplace}

To a far greater degree than is true of men, women's occupational choices and experience are shaped and restricted by their parental responsibilities. ${ }^{138}$ Women are more likely to be employed in occupations that allow part-time work, intermittent commitment, and flexible schedules, ${ }^{139}$ and thus, not surprisingly, are concentrated and segregated in lower-status, lower-paying occupations. ${ }^{140}$ To be sure, many variables contribute to this disparity between men and women besides differentiated parental roles. ${ }^{141}$ Nevertheless, as long as the ideal worker is modeled largely on the man without domestic responsibilities, women who seek to accommodate work and family obligations will continue to be limited to low-status, low-paying jobs. And it may well be true, as Daniel Fischel and Edward Lazear argue, that women "voluntarily choose lower-paying occupations." 142 Clearly, however, the voluntari-

138. This explanation for the disadvantaged position of women in the labor market is based on human capital theory, which posits that women, because of their domestic respousibilities, are less able to compete with men in the workplace. See Patricia A. Roos, GENDER AND WORK: A COMPARATIVE ANALYSIS OF INDUSTRIAL SOCIETIEs 3-5 (1985).

139. Eccles \& Hoffman, supra note 135 , at 375-76.

140. Women receive compensation (for full-time employment) at a rate of about $60-65 \%$ of that received by men. This "wage gap" has been fairly constant for 40 years. Id. Although some progress toward integration has been made since 1970, most men and woinen work in sex-segregated jobs. See id. at 375 .

141. Institutional explanations for sex segregation and discrimination focus on "tastes for discrimination" by employers, employees, and customers, and on the lack of a competitive market. Moreover, some observers argue that occupations in which woinen are concentrated (such as school teachers and nurses), becanse of the mere fact that they employ mostly women, have lower wages than other jobs requiring comparable or less skill and commitment that employ mostly men (such as plumbers, construction workers, etc.). See Mary E. Becker, Barriers Facing Women in the WageLabor Market and the Need for Additional Remedies: A Reply to Fischel and Lazear, 53 U. CHI. L. REV. 934, 942 (1986). Discrimination against women based on sexual stereotyping might also be an inportant factor explaining the wage differential. Women can be disadvantaged in hiring or advancement either because they are perceived as lacking "masculine" characteristics (such as assertiveness) deemed necessary for particular jobs or because they possess such characteristics and are thus not femimine. See Price Waterhonse v. Hopkins, 490 U.S. 228, 251 (1989) ("An employer who objects to aggressiveness in women but whose positions require this trait places women in an intolerable and impermissible Catch-22: out of a job if they behave aggressively and out of a job if they do not."); Mary F. Radford, Sex Stereotyping and the Promotion of Women to Positions of Power, 41 HAstings L.J. 471, 485 (1990). In blue-collar jobs, advancement can be impeded by hostility from males. See Becker, supra, at 944 . For a discussion of several barriers that women face in the labor market, see generally id. at 940-47.

142. Daniel R. Fischel \& Edward P. Lazear, Comparable Worth and Discrimination in Labor Markets, 53 U. CHI. L. REV. 891,897 (1986). Fischel and Lazear argue that women might make this choice because low-paying occupations have attributes that accommodate their desire to specialize in childbearing, childrearing, and household services. Women might therefore choose jobs that allow them to euter and exit without penalty and avoid occupations that require long hours, relocation, or extensive training periods. In making this choice, however, women must "pay a price in the forn of lower wages." Id. Becker challenges this analysis. See generally Becker, supra note 141. She points out that the gendered wage differential exists in occupations with comparable skills, and that women whose employment is not intermittent are not much more likely to be in maledominated oceupations. Moreover, Becker argues that Fischel and Lazear ignore the importance of 
ness of the choice is constrained by societal norms, internalized by many women, that women bear primary responsibility for their children's care and that subordinatimg this duty to a career is deviant. ${ }^{143}$

\section{b. Gender Roles and Family Participation}

The contimuing tenacious influence of traditional gender norms on attitudes and behavior challenges theories of family role allocation that prevailed until recently. In the 1960 s and 1970s, resource theory explained husbands' minimal participation in the domestic sphere as a function of occupational role and not of gender role ideology. ${ }^{144}$ Contrary to the theory's prediction, however, the movement of wives into the labor force has not resulted in a corresponding mcrease in the ainount of time fathers spend performing household tasks. ${ }^{145}$ The failure of

the background gendered power structure for determining opportunities for men and women and defining productivity. Becker also argues that women choose occupations based on internalized gender ideology. Id. at 940-44.

143. In 1985 more than half of the women responding to an attitudinal survey reported that they behieved that preschool children suffer when their mothers work. Thornton, supra note 136, at 876-77. Some child guidance experts and psychologists criticize mothers' employment when children are young. See Jay Belskey, The "Effects" of Infant Day Care Reconsidered, 3 EARLY CHILDHOOD RES. Q. 235, 265 (1988) (more than 20 hours a weck of nonmaternal care during the first year places child at risk); T. Berry Brazelton, Issues for Working Parents, in THE PARENTAL LEAVE CRISIs 36, 39 (Edward F. Zigler \& Meryl Frank eds., 1988) (describing harm of mothers' premature return to work); see also infra note 164 (discussion of day care controversy). Cynthia Epstem's research found that women who sought to mvest in careers in male-dominated professions met with disapproval, particularly if they were mothers. In her view, these women felt guilty because they internalized the belief that they were selfish. See Epstein, supra note 132, at 165. Epstein describes a "zero-sum perspective" that assumes that mothers' career satisfaction is achieved at some cost to their children's well-being. Id. at 181.

144. Resource theory was developed by Blood and Wolfe who based it on a study of the division of household tasks between husbands and wives. See RoBert O. Blood, JR. \& DoNAld M. Wolfe, Husbands \& Wives: The Dynamics of MarRied Living (1960). Resource theory posited that allocation of tasks withm a family was based on different resources such as skills and strength. See id. at 47-48. The chief resource required for domestic tasks is time; because women who do not work outside the home usually have more time than their husbands, they tend to perform the bulk of domestic tasks. Id. Blood and Wolfe concluded that husbands did a higher proportion of housework in households in which wives worked than in those in which wives did not work. Cf. id. at 62, 65-66 (finding that wives who worked performed a smaller proportion of household tasks and concluding therefore that husbands must have performed a greater proportion of domestic tasks).

Besides resource theory, exchange theory was also used to explain the gendered division of labor. John Scanzoni argued that husbands often provide objective (status, prestige, and income) and subjective (feelings of being a part of the opportunity structure) rewards to their wives in exchange for household services and companionship. See JOHN H. SCANZONI, OpPORTUNITY AND THE FAMILY 184 (1970).

145. Indeed, although the proportion of husbands' contributions to household chores is greater, as Blood and Wolfe concluded, this increase results principally from working wives spending less time, in absolute terms, performing household duties than nonworking wives. PLECK, supra note 132, at 31. According to Pleck, resource theory was discredited by several large-scale studies in the 1970s that showed that men did not increase their participation in housework and childcare greatly when wives worked. Id. at 15 . In fact, the total workload of employed wives substantially exceeded 
resource theory to provide an adequate account of differentiated family roles indicates the continuing robust influence of traditional norms on the institutions of the family and workplace.

Contemporary mothers and fathers differ both as to the quantity of time spent in child care and in the character of the parent-child interaction. ${ }^{146}$ In most cases, mothers perform the basic tasks of child care, while fathers devote proportionately more time to "play" interaction. ${ }^{147}$ More intangibly, inothers "1nanage" their children's hives by making decisions, anticipating needs, and responding to problems. ${ }^{148}$ This is not to suggest that the father-child relationship is unimportant to the child's development. $^{149}$ In inost families, however, including those in which both parents are employed, mothers function as primary and fathers as

that of their husbands. Studies have found that employed wives work a total of 1.3 to 2.4 hours more per day than their husbands. Id. For a discussion of research on time studies of family and paid work, see $i d$. at 27-54.

As men have become hiberated from the "good provider" or "breadwinner" role over the past several decades, two trends have emerged. See Frank F. Furstenberg, Jr., Good Dads-Bad Dads: Two Faces of Fatherhood, in The Changing American Family and Public Policy, supra note 132, at 193, 198-200. Fathers in intact families have become somewhat more active participants in the family. Id. at 199, 206-09. At the same time, many men have rejected the breadwinner role by failing to pay child support after divorce. Id. at 199-200, 202-03; see also Joseph H. Pleck, Husbands' Paid Work and Family Roles: Current Research Issues, in 3 RESEARCH IN THE INTERWEAVE OF SOC1AL Roles: FAMILIES AND Joes 251, 262-63 (Helena Z. Lopata \& Joseph H. Pleck eds., 1983) (some studies have shown that husbands' increased participation in childeare, as opposed to other domestic tasks, has been modest).

146. In mtact families, fathers participate little in routine caretaking tasks. One study found that fathers in upper-middle and professional class families spent an average of 15 to 20 minutes a day with their infant children. Peggy L. Ban \& Michael Lewis, Mothers and Fathers, Girls and Boys: Attachment Behavior in the One-Year-Old, 20 MerRill-Palmer Q. 195, 202 (1974). For an excellent review of relevant research, see Thompson, supra note 51, at 65 (citing numerous studies about fathers' minimal participation). In inost cases, motliers continue to perform most basic caregiving tasks such as feeding, bathing, and preventative proteetion from harm. Id. at 66 . For a comprehensive discussion of this research, see Chambers, supra note 4, at 533-34.

147. Thompson, supra note 51 , at 66,72 . By age two, children in studies preferred fathers for play. See Jay Belsky, Mother-Father-Infant Interaction: A Naturalistic Observational Study, 15 Developmental Psychol. 601, 605-06 (1979) (infants are more likely to move toward and more likely to vocalize and show things to their fatlers); Thompson, supra note 51, at 69, 71-72 (infants showed a more friendly, positive responsiveness to fathers than motliers). On the other hand, small children turn to their mothers for coinfort when tired, anxious, or otherwise stressed. See id. at 7072. This differential response suggests that the relationships young children have with their fathers and mothers differ in their salience. See Michael E. Lamb, The Development of Social Expectations in the First Year of Life, in INfant Social CognrTion (Micliael E. Lamb \& L. Sherrod eds., 1981).

148. See Furstenberg, supra note 145, at 209 (the father often serves as the "babysitter" rather than the "orchestrator of the child's activities"). While arguing that fathers in two-parent families usually play a central part in children's lives despite mediating factors, one commentator has acknowledged that the father's relationship to the child is often mediated by the role of the mother. See Chambers, supra note 4 , at 535.

149. To the contrary, from an early age children demonstrate emotional attacliment to their fathers, who serve as role models and disciplmarians. See Chambers, supra note 4, at 534-35. In addition to this emotional attachunent, Thompson argues that fathers play an important part in the intellectual development of their children. See Thompson, supra note 51, at 68-70, 72-73. 
secondary caregivers. ${ }^{150}$

\section{Explaining the Slow Pace of Gender Role Change}

Some feminists argue that the slow progress toward shared parental roles represents an unambiguous effort by men to keep women in a subordimated status. ${ }^{151}$ This account seems imcomplete, however, in part because it fails to explain for the resistance of women to the reformulation of traditional gender roles. ${ }^{152}$ Despite the apparent benefits, the proportion of women who fully subscribe to a goal of shared parental roles is small. ${ }^{153}$ An examination of the nature of gender norms and of the complex forces that influence their evolution explains in part why change has been slower and shallower than it appears and how the ambivalence of both men and women contributes to the pace.

150. Thompson, supra note 51 , at 66 .

151. See Margaret Polatnick, Why Men Don't Rear Children: A Power Analysis, 18 Berkeley J. Soc. $45,60-79$ (1973). Some feminists also argue that men encourage women's financial dependence, which reinforces their subordinated position. See, e.g., id. at 64. If women are forbidden from working or bear primary responsibility for domestic tasks, they are disabled from competing effectively for power and resources in society. See JoHN K. Galbraith, Economics AND THE PUBlic PURPOSE 58-60 (1973) (women doing household tasks are "crypto-servants" performing merial personal tasks); Heidi I. Hartmann, The Family as the Locus of Gender, Class, and Political Struggle: The Example of Housework, 6 SIGNS: J. WOMEN CULTURE \& Soc'Y 366, 385 (1981) (household labor by women confers patriarchal benefits upon men); Pat Mainardi, The Politics of Housework, in SisTerHOOD IS POWERFul 501 (Robin Morgan ed., 1970) (the allocation of housework to women is a form of oppression or exploitation by men); Polatnick, supra, at 64 (allocating childrearing to women assures male domination of work world).

152. Moreover, soine researchers argue that many men get less intrinsic satisfaction from their work role than this critique suggests and that men view their work role primarily as a means of fulfilling their breadwinner role. See, e.g., Daniel Yankelovich, The Meaning of Work, in THE WORKER AND THE JOB 19, 44-45 (Jerome M. Rosow ed., 1974) (suggesting that only approximately one-fifth of men find their psychological needs fulfilled by work).

153. Many woinen do not express a desire for husbands to contribute more to housework and child care. See PlEcK, supra note 132, at 33, 44-45, 90-92 (finding that women perform substantially more domestic tasks than their husbands, but only about one third express a desire for husbands to do more); Deborah L. Rhode, The "No-Problem" Problem: Feminist Challenges and Cultural Change, 100 YALE L.J. 1731, 1759, 1774 (1991) (suggesting that despite increasing percentages of wives who want husbands to perform more domestic tasks, many women do not feel that their disproportionate assumption of domestic responsibilities is unjust).

Large-scale surveys of family and work often include a few iteins about gender role attitudes that are directed at assessing whether respondents reject traditionalism or not. As Pleck points out, however, many such surveys fail to explore the extent to which fully egalitarian roles are embraced. The reason for this is that in representative samples, most respondents reject egalitarian values. PLECK, supra note 132, at 75. Thus, researchers omit such questions from their final questionnaires because these items will yield little variation in response. Id. at 75-76.

The following are examples of the types of survey statements presented to respondents in studies designed to measure changes in gender attitudes with which respondents were directed to express their level of agreement: “"There is some work that is men's and some that is women's, and they should not be doing each others" " ; "Women are much happier if they stay at home and take care of their children'"; "The husband should make all inportant decisions in the family" "; " 'It's perfectly all right for women to be very active in clubs, politics, and other outside activities before the children are grown up.' " Thornton, supra note 136, at 877 (table of survey questions). 
Gender roles are grounded in ascribed traits and are deeply rooted in personal identity; thus, they are quite resistant to change. ${ }^{154}$ From infancy onward, men and women are exposed continuously to differentiated societal expectations based on sex. ${ }^{155}$ These expectations are institutionalized as societal norms and become internalized in both men and women. ${ }^{156}$ Although the inessage is surely softened in the inodern context, female children continue to absorb from society that self-fulfillment is found first through inarriage and notherhood, while for male children self-fulfillment is inore often equated with success in the broader world beyond the family. ${ }^{157}$

Sociological theory posits that inaintenance of differentiated gender roles depends on evidence or behef that differentiation is either natural or efficient. ${ }^{158}$ Some economists have argued that differentiated family and work roles represent an efficient division of labor, and thus naximize family welfare. ${ }^{159}$ This rationale, although it nay sometimes support

154. For a sociological discussion of theories of gender role differentiation and stratification (hierarchy), see HARRIET Holter, Sex Roles aNd Social Structure (1970). Holter points out that gender role differences have been found in every society. Id. at 18. She emphasizes the importance of the ascribed character of gender roles and contrasts this feature with role differentiation based on achievement. Id. at 19-23. Mobility to other social positions is far easier when role differentiation is based on performance and preference. Id. at 19-20. Holter reports that sociologists have had httle interest in norms based on ascribed criteria. Id. at 20.

155. See infra note 157.

156. See HoLTER, supra note 154, at 41-42. Gender role norms are reinforced through primary and secondary rewards. Primary rewards include social approval received by conforming to gender role expectations. Id. at 34-35. For example, boys (more than girls) receive approval for acting assertively. Secondary rewards are more indirect responses. Thus, assertive boys might gain leadership positions. See id.

157. For example, parents have different expeetations for sons and daughters. Parents are more likely to emphasize achievement and competition with sons than with daughters. Jeanne H. Block, Another Look at Sex Differentiation in the Socialization Behaviors of Mothers and Fathers, in THE Psychology of Women: FUtURe Directions in Research 29, $74-75$ (Julia A. Sherman \& Florence L. Denmark eds., 1978). Parents therefore probably have grcater career and academic expeetations for sons than daughters. In addition, different qualities are valued in sons and daughters. Parents are more likely to describe success, anbition, and intelligence as qualities they want sons to develop, while they are more likely to hope daughters will be kind, attractive, wellinannered, and will have a good marriage. See Eccles \& Hoffinann, supra note 135, at 391-93. Other influences on gender role development that reinforce differentiation mclude television, school experience, and athletic programs. See generally id. at 393-407.

158. See HoLTER, supra note 154, at 21 . The belief that differentiation is natural presumes that two groups differ in inborn capacities. This, of course, often reinforces differentiation based on efficiency. Differentiated roles can also be sustained if supported by a belief that they are divinely ordained. See id. Such beliefs, although once important in supporting gender roles, are less influential today. Indeed, the secularization of gender role differentiation has been important in weakening ascribed roles. Id. at 22.

159. See, e.g., Gary S. Becker, The Economic Approach to Human Behavior 108 (1976) ("Members who are relatively more efficient at market activities would use less of their time at consumption activities than would other members."). But see Richard A. Berk, The New Home Economics: An Agenda for Sociological Research, in WOMEN AND HOUSEHOLD LABOR 113, 124-25 (Sarah F. Berk ed., 1980) (pointing out anomalies in Becker's argument). 
dividing domestic and employment roles between spouses, ${ }^{160}$ does not explain a pattern of systematically assigning primary domestic responsibilities to women and financial support obligations to men. The deeper, more entrenclied claim is that men and women liave different characteristics and competencies that make differentiated gender roles efficient. Stereotypical beliefs about male aggressiveness, competitiveness, and rationality contimue to support male dominance in the workplace. ${ }^{161}$ Similarly, an implicit belief that women liave a special capacity for nurturing persists, sliapmg attitudes and beliavior of botli men and women.

Today, women continue to receive and internalize many societal signals that children need primary care from tlieir mothers. ${ }^{162}$ Attachment theory, whicl empliasizes the motlier-child relationship as crucial to liealtliy child development, continues to influence popular culture, altliougli its scientific basis lias eroded. ${ }^{163}$ Furtlier, the ongomg controversy over day care focuses on whetlier substitutes for inaternal care are

160. The gender-based allocation of tasks in dual career families might be perceived as efficient if the husband's freedom to pursue career objectives inaximized benefits for the whole family. Another efficiency argument against shared parenting roles is that restructuring the faunily by "retraining" fathers to perform child care and domestic functions will be costly to fainilial wellbeing. See HolTER, supra note 154, at 28-30; see also PLECK, supra note 132, at 92 (suggesting that wives might not want husbands to perform more child care because of difficulties that might arise in training them to perform tasks competently). One challenge to this argument is that general productivity would imcrease if women were more fully employed. See HolTER, supra note 154, at 29-30.

161. Those kinds of stereotypical beliefs about gender roles can hurt women in the workplace in two ways. First, women can be discriminated against because they fail to exlibit feminine gender traits. See Price Waterhouse v. Hopkins, 490 U.S. 228 (1989). For example, the plaintiff female employee who was demed partnership in Price Waterhouse was described by partners as " 'macho," " as " "overcompensat[ing] for being a woinan," " and as needing " 'a course at cliarm school." " Id. at 235 (quoting Defendant's Exhibit 27-31). Second, women can also be disadvantaged because of a belief that they do exhibit stercotypical gender traits that are not desirable. Cf. EEOC v. Sears, Roebuck \& Co., 628 F. Supp. 1264 (N.D. Ill. 1986), aff'd, 839 F.2d 302 (7tl Cir. 1988). Sears successfully defended against a Title VII discrimination claim for failing to liirc female applicants for commission sales jobs on the same basis as male apphicants. Sears had argued that surveyed women employees lacked imterest in high-paying competitive commission sales jobs, preferring limited work commitment in a supportive environment so that they could fulfill domestic responsibilities. Id. at 1305-15. For an imsightful discussion of the Sears case, see Williams, supra note 36, at $813-21$ (arguing that Sears used gender stereotypes to defend against the Title VII claim).

162. See supra note 143 (describing attitudes toward maternal responsibility). Evidence of these signals and their power is contained in findings of research about noncustodial mothers. Fischer found that noncustodial mothers were viewed as uncommon and met with significant societal disapproval (exceeded only by liomosexual couples) in evaluations by faculty and graduate students. See Fisclier, supra note 59, at 351-52.

163. See supra note 47 (overview of attachinent theory). The researcl by Bowlby and Ainsworth and others that formed the basis for this thcory involved studies of mothers and cliildren, and hence the theory is delimited by this relationslip. More recently, however, some resenrchers have foeused on the father-child relationship; as I have suggested, there is growing recognition of the integral importance of this relationship to healthy child development. See supra notes 51, 147-49. Moreover, the traditional view that mothering is a "natural" function for women grounded in biology is less commonly held today. See Rhode, supra note 153, at 1747-49, 1784-85. Some believe 
detrimental to children's psychological growth. ${ }^{164}$ Many working women experience ambivalence about their reduced availability to their children, reflecting a common belief that mothers have a special, nonfungible ability to meet their children's needs. ${ }^{165}$ This belief surely influences many women to accommodate their career choices to the demands of the maternal role. ${ }^{166}$

Women might also embrace their ascribed role because the intrinsic value of the childrearing function obscures their subordinated status. ${ }^{167}$ Indeed, havimg been assigned this important societal function, women might be inclined to assert a territorial claim, resisting the notion that inen can readily step into the role. ${ }^{168}$ If the obligations and functions

instead that women's competency and aptitude for mothering reflect culturally constructed gender roles. See id. at $\mathbf{1 7 8 5}$. As gender roles converge, men's nurturing "instincts" might be enhanced.

There is no evidence that men are inherently less competent at parenting than women. See Furstenberg, supra note 145, at 206 (mothers' unique parenting capabilities have not been substantiated). Men who assume primary caretaker roles function capably and are not disabled by their gender. Id. Some psychologists beheve that having two primary caretaker parents is beneficial to children, as it provides a richer family experience with two adult role models and companions and offers stability and continuity of care even im the ongoing marriage. See Lamb, supra note 47, at 3233. Evidence of the continued popular interest in attachment theory, however, is suggested by a recent cover story in a popular magazine. Robert Karen, Becoming Attached, ATLANTIC MoNTHLy, Feb. 1990, at 35.

164. The debate about infant day care divides those who interpret the research findings to show that infants in day care face an increased risk of einotional insecurity and social maladjustment and those who hold that the data do not support these claims and that other variables such as family characteristics or maternal responses are determinative. Compare Peter Barglow et al., Effects of Maternal Absence Due to Employment on the Quality of Infant-Mother Attachment in a Low-Risk Sample, 58 CHild DEv. 945 (1987) (infant day care creates risk of insecure mfant-mother attachment) and Belsky, supra note 143, at 257 (more than 20 hours per week of nonmaternal care in the first year places child at risk of insecurity in infancy and adjustment problems in the preschool and early school years) with K. Alison Clarke-Stewart, 'The 'Effects' of Infant Day Care Reconsidered" Reconsidered: Risks for Parents, Children, and Researchers, 3 EARLY CHILDHOOD RES. Q. 293 (1988) (arguing that Belsky's data do not provide clear evidence that day care places infants at risk of emotional maladjustınent) and Deborah Philips et al., Select Review of Infant Day Care Research: A Cause for Concern!, ZERO TO THREE, Feb. 1987, at 18 (arguing that Belsky selectively employs research findings). Interestingly, one measure of the detriment to infants in day care is the extent to which such care disrnpts attachment to the mother (suggesting the primacy of the mother-child relationship). For an excellent discussion of the controversy surrounding the research assessing infants' relationships with their mothers, see $\mathrm{K}$. Alison Clarke-Stewart, Infant Day Care: Maligned or Malignant?, 44 AM. PsYCHologist 266 (1989).

165. Brazelton describes how working inothers of infants feel a sense of loss and competition with substitute caregivers. Brazelton, supra note 143 , at 46.

166. See Williams, supra note 36 , at 823,833 (women continue to marginalize thernselves economically in order to fulfill child care responsibilities through part-time work, " 'sequencing," " the " 'mommy track," " or " "women's work' ").

167. See Rhode, supra note 153 , at 1774 ("Simce many women also believe that caring for a home and children are their most rewarding pursuits, their disproportionate assumption of domestic burdens inay not always feel unjust.").

168. For a discussion of relevant research, see supra note 153. Berk found that both husbands and wives expect wives to assume a large share of family work and that both are satisfied with the division of household labor. SARAH F. BERK, THE GENDER FActory: THE APPORTIONMENT OF WORK IN AMERICAN HousEholds 207 (1985); see also Rhode, supra note 153, at 1774 (women 
that have long defined women's identity can be readily performed by their male mates, then the unique character of the nuaternal role and of women's special competency becomes uncertain. This response might be reinforced by women's restricted access to power and resources in the broader society. ${ }^{169}$

Women do not seek more aggressively to discard ascribed gender roles for another reason. Although they are disadvantaged relative to men in terms of power and resources, this disparity is obscured by the fact that many women hive imtimately with inen and share the social status and resources of their inates. In comparison to victims of racial hierarchy, women's exclusion is often mdirect and muted-as long as they are married. Thus, the disadvantage associated with differentiated gender roles inay generate dissatisfaction only upon divorce. Until then, such roles can seein to be an efficient (and normatively desirable) allocation of labor. ${ }^{170}$

Men are also ambivalent about shared family roles. ${ }^{171}$ On the one hand, men hiving in intimate relationships with women presumably care about their mates' happiness, and if women desire fulfillment beyond the domestic sphere, many men are likely to respond supportively. Moreover, as inen becoine more confident about their nurturing capacities, they inay be notivated to invest in parenthood beyond the traditional boundaries of the father's role. On the other hand, men might have an incentive to inamtain traditional roles because gender equality threatens male power, status, and autonoiny. Moreover, pressure to succeed in socially defined inasculine roles inay reinforce nien's resistance to accepting a larger doniestic role. ${ }^{172}$

might not think that it is unfair that they assume a disproportionate amount of domestic responsibilities). Epstein points out that mothers' sex-role attitudes play a "gatekeeping" role that can facilitate or discourage fathers' increased participation in domestic tasks. See Epstein, supra note 132 , at 173. The proportion of wives who desire greater assistance from their husbands in domestic work has steadily increased in recent years, but contimues to be a minority position. PLECK, supra note 132 , at 90 .

169. See Rhode, supra note 153, at 1751-55, 1764 (discussing gender bias in academic and employment settings).

170. See supra notes $159-60,168$ and accompanying text (satisfaction in division of roles).

171. See Rhode, supra note 153, at 1772 . Rhode states that "too many men view rhetorical support for women's aspirations as an adequate substitute for more tangible personal and political commitments." Id. Further, "the skewed allocation of donestic responsibilities reveals wide disparities between many husbands' professed principles and daily practices. ... [M]any husbands find ways to deny or rationalize their lighter burden." Id.

172. See Benson Rosen \& Thomas H. Jerdee, Infiuence of Sex Role Stereotypes on Personnel Decisions, 59 J. ApPLIED Psychol. 9, 9 (1974) (arguing that inen are expected to pursue their careers with single-minded dedication). The occupational success of men inight be threatened by additional domestic responsibihities because any intrusion of family or other personal matters is viewed unfavorably by employers. Id. A social psychology study of sex role stereotyping found that employers, presented with hypotheticals, were less sympathetic to inale accountants' requests for leave to care for small children than they were to requests by fenale accountants. Id. at 12-13. In 
The implication of these observations for custody policy is important and has gone largely unheeded. Those who argue that custody law can effectively proinote fundamental change in the allocation of parenting responsibilities discount the formidable character of resistance by both men and women to gender role change. To be sure, as sociological theory predicts, ascribed gender roles are slowly changing and converging as the efficiency rationale supporting role differentiation loses strength. On one level, many woinen recognize their exclusion froin the power and resources of society and are motivated to pursue avenues of self-fulfillment beyond the family. Many forces work to slow the novement toward the convergence of parental roles, however, including the continuing inclination of inodern wornen to internalize conventional societal norms defining the maternal role.

\section{B. Social Norms and the Regulation of Family Relationships: The Fallacy of Legal Centralism}

It is evident that legal policy initiatives to proinote the convergence of gender roles face a formidable challenge. ${ }^{173}$ Nonetheless, in the public sphere there is reason to beheve that regulation can eventually lower barriers to full participation by women in education and employinent, and influence the culture of the workplace toward one that presumes that most workers, male and female, have significant family responsibilities. Relationships within the family are far less amenable to legal monitoring, ${ }^{174}$ however, and regulatory initiatives that seek directly to alter fam-

addition, some men might still believe that if they fill their breadwinner role adequately, their wives sliould not have to work. See Furstenberg, supra note 145, at 195-98 (discussing the rise and declime of the "good provider" role). In general, men do not differ significantly from women in their attitudes towards men's increased participation in family work. PLECK, supra note 132, at 81.

The experience of the Swedish parental leave policy, designed in part to increase fathers' parental participation, suggests low formidable male resistance can be. The Swedish government, in 1974, mitiated a policy of offering parents several inonths of paid leave around the time of a child's birth. Michael E. Lamb \& James A. Levine, The Swedish Parental Insurance Policy: An Experiment in Social Engineering, in FATHERHOOD AND FAMILY POLICY, supra note 51, at 39. Fathers seldom took advantage of the opportunity to stay home with their young children. Id. at 43-47. One study sliowed that less than $10 \%$ of fathers took even one day of paid parental leave. Id. at 45 . One explanation might be fear of employer disapproval. Some anecdotal evidence appears to support this hypothesis. Id. at $49-50$.

173. The struggle in this country to combat racial discrimination suggests the enormity of the task of breaking down norms based on ascribed traits. Even though the nnderlying values and norms supporting racial eqnality have substantial support in our society, legal mechanisms to combat racial discrimination have had, at best, modest success.

174. Although legal reforms dealing with employment, education, and other pnblic spheres might meet with snbstantial resistance, these settings are more amenable to legal monitoring because they are public and because individuals and institutions are more likely than are family members to be in arm's length relationships. Cf. Lon L. Fuller, Human Interaction and the Law, in THE RULE OF LAW 171, 212 (Robert P. Wolff ed., 1971) ("[T] inept instrument for regulating intimate relations are precisely those which lend to it a special capacity to put in order men's interactions within the larger impersonal society."). 
ily roles are likely to be more costly and less satisfactory than efforts in the public sphere.

Scholars have increasingly expressed skepticism about the efficacy of legal regulation of the family and other informal long-term relationships. Robert Ellickson and others have argued persuasively that legal centralism, a construct that asserts the preemptive role of the state as a source of social control, ignores the powerful regulatory function of informal social norms that define appropriate behavior and form the basis of expectations in ongoing social relationships. ${ }^{175}$ Researchers have found that relationships between neighbors, ${ }^{176}$ employers and servants, ${ }^{177}$ and business persons and customers ${ }^{178}$ are regulated largely by informal norms. For this reason, such relationships may be relatively impervious to efforts of legal reformation. ${ }^{179}$

Legal regulation might be particularly ineffective in regulating relationships among family members, whose interactions involve an intricate pattern of exchanges, decisions, assignments of tasks, and spheres of authority that is shaped by preferences, values, and external pressures.

175. See Robert C. Ellickson, A Critique of Economic and Sociological Theories of Social Control, 16 J. LEGAL STUD. 67, $81-90$ (1987). Economist Oliver Williamson first used the term "legal centralism" to describe a belief that Ellickson attributes to law and economics scholars. See id. at 81. Although some sociologists have focused on law as the principal mechanism of social control, many have recognized its peripheral role in resolving confiicts between intimates. See, e.g., Donald Black, Social Control as a Dependent Variable, in I TOWARD a GENERAL THEORY OF Social Control: Fundamentals 1, 3 (Donald Black ed., 1984) (people who have close relationships use little law against one another). In his own empirical study of the resolution of disputes between ranchers and farmers regarding trespassing cattle, Ellickson found that disputes were resolved with little reference to the parties' substantive legal rights. See Robert C. Ellickson, Of Coase and Cattle: Dispute Resolution Among Neighbors in Shasta County, 38 STAN. L. REv. 623, 671-86 (1986) [hereinafter Ellickson, Coase and Cattle]. Rather, parties adhered to informal social norms that dictated responsibilities. Id.; see also Robert E. Scott, Conflict and Cooperation in LongTerm Contracts, 75 CALIF. L. REv. 2005, 2040-42 (1987) (discussing social norms such as reciprocity, lonesty, trust, and solidarity that play important roles in regulating seller-buyer contractual relationships).

176. See, e.g., Ellickson, Coase and Cattle, supra note 175, at 671-85.

177. See, e.g., Vilhelm Aubert, Some Social Functions of Legislation, 10 ACTA Soc1oLOGICA 98 (1967). Aubert studied the effect of the 1948 Norwegian Law of Housemaids on the relationship betwecn domestic servants and their employers. See id. at 98 . The law, enacted to control hours and otherwise to improve working conditions for servants, did little to change behavior. See id. at 98-99. In approximately half of the 233 households studied, the ten-hour working day was exceeded. Id. Only $10 \%$ of the sampled relationships showed complete compliance with the law. Id. Aubert points out that legal regulation was difficult because "[t]he law concern[ed] an area traditionally assumed to be proteeted against public inspection and control, the liome," and because of the intimate (family-hike) and strong nature of the relationship betwecn servant and master. Id. at 105 .

178. See, e.g., Stewart Macaulay, Non-Contractual Relations in Business: A Preliminary Study, 28 AM. Soc. REV. 55, 58-61, 63-64 (1963) (finding that commercial buyers and sellers often operated according to informal noruns, sucl as standing behind the product or a person's word is a bond, that went beyond contractual obligations).

179. Relationships that are largely influenced by social norms and not by laws might remain unaffected when laws change. See Aubert, supra note 177, at 116 (Norwegian housemaid law had very little effect on working conditions six years after passage). 
Lon Fuller has argued that norms, or "customary law," regulate family relations more effectively than do formal legal enactments because norms structure conduct into roles and functions that create stable expectations. ${ }^{180}$ Analogous efforts through legal regulation would probably require an extreinely coinplex set of rules that could be enforced and monitored only at great cost. Except for defining the outer limits of acceptable behavior (definitions that also track social norms), ${ }^{181}$ the law seldonı atteinpts to regulate relationships, dictate functions, enforce obligations, or resolve conflicts within the intact family. ${ }^{182}$ Extensive unanipulation of family interactions not ouly would incur formidable enforcement costs but would involve intrusive invasions of family privacy by the state. The idea of a court directing parents to reallocate their child care and occupational responsibilities in an intact family has an Orwellian flavor that would be highly offensive to most people, even those committed to the social goal of shared gender roles.

\section{Divorce and Legal Regulation of Family Roles}

The curtain of family privacy is lifted upon divorce. Some judicial involvement is necessary to supervise the dissolution of the legal relationship and to reallocate the couple's property rights. Legal oversiglit also serves to reinforce informal social norms, weakened in the context of divorce, by directing parents to fulfill their prescribed responsibilities despite the breakdown of the marriage. Thus, for exaniple, mothers are legally directed to give fathers the opportunity to continue their relation-

180. See Fuller, supra note 174, at 212. In contrast to enacted law, customary law is not limited to requiring or prohibiting specific acts. $I d$.

181. For example, rules prohibiting child abuse define the outer limits of parents' freedom to discipline their children according to their own normative prescriptions. Fuller comments that the function of enacted law in regulating relationships in the larger society is to "impose rules that will serve to set the limits men must observe in their interactions with one another, leaving them free within those limits to pursue their own goals." Id. at 212-13.

182. For example, sometimes the theoretical duty of husbands to support their wives was not enforced in ongoing marriages, regardless of how inadequate the hnsband had been in performing his duty. See, e.g., McGuire v. McGuire, 59 N.W.2d 336 (Neb. 1953) (holding that wife could not maintain an action for support absent separation from her husband). In McGuire, the court stated that "[t]he living standards of a family are a matter of concern to the honsehold, and not for the courts to determine, even though the husband's attitude toward his wife ... leaves hittle to be said in his behalf." $I d$. at 342 .

This is not to say that the law has no effect on relationships in the intact family. Some femimists have argued that the law's stance toward the family has reinforced male dominance both explicitly and implicitly. See Frances E. Olsen, The Family and the Market: A Study of Ideology and Legal Reform, 96 HARV. L. REV. 1497, 1509 \& n.53, 1510-12 (1983). The historical treatunent of unarital rape, the authority of parents to physically punish children, and the traditional rules regarding marital domicile are all examples of legal rules that reinforce hierarchal power relationships within the family, often in a cloak of nomintervention. $C f . i d$. On the other hand, married women's property acts in the 19th century increased the economic power of married women vis-á-vis their husbands, again without direct intervention. Id. at 1531-32. Nevertheless, legal directives that husbands and wives must fill certain roles in the family, with sanctions for noncomphance, are rare. 
ship with their child, while fathers must continue to provide financial support. ${ }^{183}$ Modern custody law, whether inadvertently or purposefully, assunies a more interventionist stance. It presunies that courts can redesign family relationships and restrncture parental roles without regard to the past practices and preferences of the parents. As I have demonstrated, no conventional custody rule adequately recognizes the limits of legal intervention in this context, or acknowledges the costly task of future momitoring and enforcement necessary if the parties do not readily adjust to their externally defined roles.

Perhaps the legal response is not surprising in a period when no norinative or positive consensus announces how parents should share responsibility for their children. Lacking such a guide, custody law presumes that variety among families means that individual families will adapt to whatever arrangements courts direct. As I have argued, however, the absence of consensus does not mean that parents casually assigu family roles or that the choices are value-neutral. In an era of flux and controversy about gender norms, each couple's childrearing arrangement is likely to be a stable reflection of the preferences of the couple, shaped by a customized formula of values, goals, skills, experience, and other internal and external constraints.

\section{Joint Custody and Parental Roles}

Given the power of traditional gender norins and the limited effectiveness of legal regulation of family relationships, a rule favoring joint physical custody appears to be an idealistic but ultimately unsuccessful effort to reform parental roles by fiat. Although in theory joint custody might seem to be the optimal expression of a societal commitnient to shared parenting, in practice it is likely to succeed mostly in families in which predivorce roles reflect the patterns of shared responsibility that joint custody posits. In other families, resistance and disruption are predictable as former spouses deal with one another and their children in unfamiliar roles, and legal enforcement mechanisms often will be ineffective in promoting comphance with court-defined roles.

The empirical evidence on joint custody described earlier can be interpreted in this hight. ${ }^{184}$ The fact that parents are more likely to agree

183. A modern example of legal reinforcement of informal family norms is the increasing inclination of courts to order parental support upon divorce for the college education of children who are no longer minors, even though parents have no legal obligation to provide this type of support during marriage. The analysis may take into account whether a given parent would have provided sucl support in the intact family. See, e.g., Childers v. Childers, 575 P.2d 201 (Wash. 1978) (holding that trial court did not abuse its discretion in ordering father to pay for children's education). Such support orders represent legal reinforcement of social norms regarding parental duty of support that may have eroded because of family dissolution. See id. at 207-08.

184. See supra notes 67-70 and accompanying text (noting the instability of court-ordered joint custody arrangements). 
to joint custody if fathers have been involved parents ${ }^{185}$ suggests the link between predivorce parental roles and postdivorce custody arrangements. So also does the widespread acceptance of joint legal custody by mothers as well as fathers, and the lukewarm response to joint physical custody. ${ }^{186}$ Moreover, the evidence that many joint custody arrangements actually mirror sole custody and visitation might suggest that established parenting patterns tend to persist despite legal reordering of family relationships. ${ }^{187}$ Finally, the observed instability of mandatory or coerced joint custody arrangeinents may be due, in part, to parental resistance to new roles. Conflict about commitınent, parenting competency, motivation, values, and even style of care and discipline are predictable in this situation.

In sum, although joint custody expresses a societal goal of shared parental roles better than alternative custody rules, the effort to promote ideological change in the family by mandate is improvident. Rather than conforming to legal expectations, the typical family may respond by either continuing to follow preexisting family norins (and ignoring the legal directive) or by undermining the arrangement to the child's detriment. In either case, the costs of legal enforcement will be high, and little progress is likely to be made toward the desired social goal. Those who argne that a legal preference favoring joimt custody will expedite gender role change focus on the law's expressive function. A joint custody law, however, functions not only symbohcally but also coercively to restructure the delicate and intimate patterns of family relationships. In this latter function, its operation will be costly and unsatisfactory.

\section{The Approximation Framework and Family Role Change}

In an era in which no consensus defines family roles, the approximation framework responds to normative variation among families by recognizing and reinforcing the existimg pattern of child care in each family. Through this approach, custody law subtly encourages desirable reforin without seeking to coercively restructure complex family relationships. The approximation framework affirms the desirability of shared parental roles when parents' relationships reveal a history of shared responsibility.

185. See Lowery, supra note 55 , at 312 .

186. See supra notes 65-66 and accompanying text. Although joint custody laws have been widely promoted, EMERY, supra note 45 , at 129, many fathers might not want new responsibilities or an expanded parental role. Some advocates for mothers have resisted joint custody laws and oppose mandatory joint custody orders in part because such arrangements diminish the maternal role. See, e.g., Schulman and Pitt, supra note 35, at 570-71. Some mothers also resent claims of entitlement by fathers to participate in their children's hives after divorce in a inanner that substantially alters and expands their involvement in the family. See id. Moreover, mothers might be skeptical about fathers' coinpetency or commitment to the task of parenting. See supra note 160.

187. See supra notes 67-68 (discussing "drift" toward mother custody even after fathers were awarded sole or joint physical custody of children). 
Further, by recognizing the role allocation that each couple has adopted, this framework removes barriers to the evolution of parental roles erected by legal rules that order exclusive custody in one parent. In practice, such rules often tend to distort and discount the father's family participation by recognizing only the contribution of the primary caretaker. This distortion has undesirable behavioral effects as well. Parents are encouraged to adhere to stereotypical gender roles, and fathers are discouraged from making a greater investment in the parent-child relationship. In contrast, the approximation framework signals to parents who want to escape from the constraints of traditional parental roles that custody law will support their choices. Investment in parenting will be protected upon divorce. This approach will disappoint those who believe that custody law can serve as an ambitious tool of social reform. The frainework does not seek to reform by promoting conformity in those families whose values and relationships are more traditional. My contention is that custody law will be ineffective and, indeed, harmful if it adopts this stance.

This framework offers the best available response to the dileinma of custody in a society in which each family functions according to an individual formula of values and preferences. If all, or even most, parents fully shared child care responsibilities, a joint custody rule would reflect a normative consensus about egalitarian parental roles. ${ }^{188}$ We are not at that point. Until we are, custody law can best support the objective of encouraging shared parenting by signalling that it will be recognized on divorce, not by atteinpting to reform families who follow a different normative plan.

188. Under these circumstances and because of its precision, a joint custody preference would also be the optimal background bargaining rule. See supra Section III.C.2 (discussing the importance of a precise rule from which parties can bargain). 